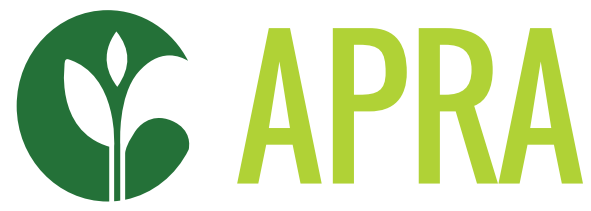

Agricultural Policy Research in Africa

\title{
LAND AND LABOUR RELATIONS ON COCOA FARMS IN SEFWI, GHANA: CONTINUITY AND CHANGE
}

Joseph A. Yaro, Joseph K. Teye and Steve Wiggins 


\section{TABLE OF CONTENTS}

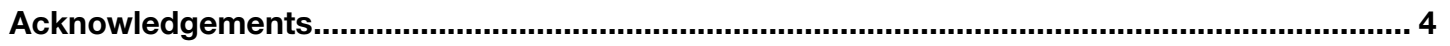

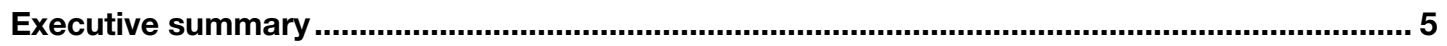

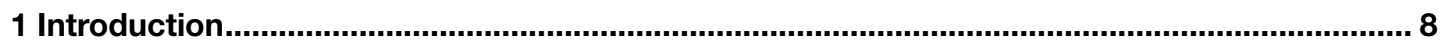

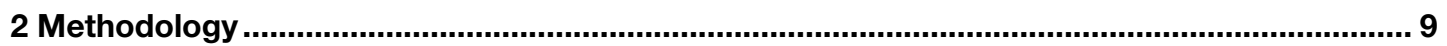

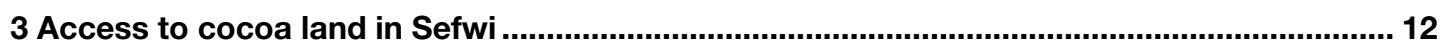

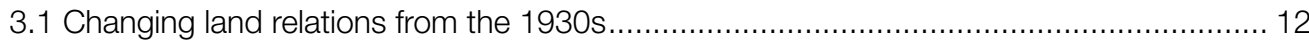

3.2 Contemporary dynamics in access to land for cocoa............................................... 13

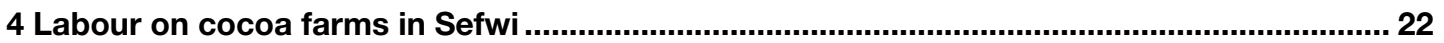

4.1 Changing labour relations in cocoa production in Ghana .......................................... 22

4.2 Labour forms and dynamics in cocoa farms in Juaboso Municipal................................ 23

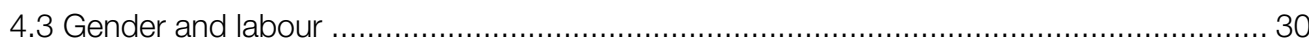

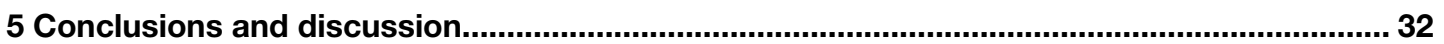

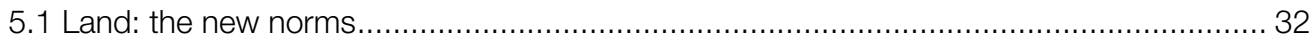

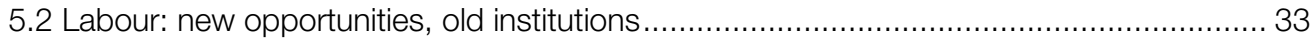

5.3 Women at a disadvantage, even if some improvement has been seen........................... 33

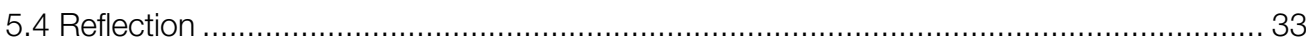

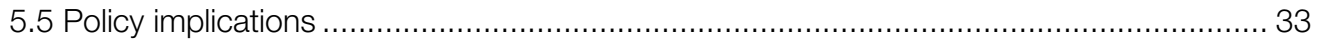

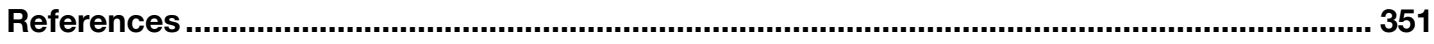

Tables

Table 2.1: Qualitative methods showing the number of interviewees .................................. 9

Table 2.2: Number of survey respondents in sampled communities ..................................... 11

Table 3.1: Land acquisition in Sefwi: forms and conditions............................................ 13

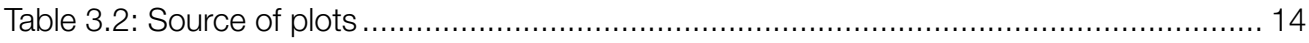

Table 3.3: The proportion of land sales with documents by gender for Juaboso.................... 18

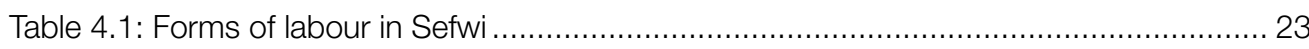

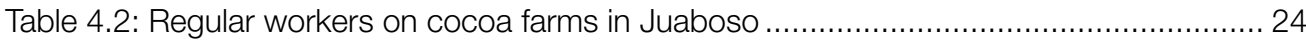

Table 4.3: Proportion of respondents who worked for others for more than 10 days in last

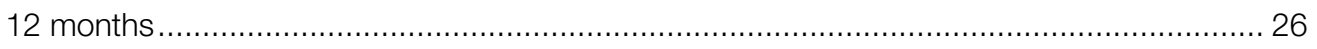

Table 4.4: Use of hired labour: number of famers hiring for specific tasks............................ 26

Figures

Figure 2.1: Focus group discussion held during the reconnaissance survey in

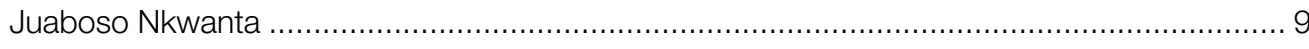

Figure 2.2: Juaboso Municipal District, Western North Region, with study sites ................... 10

Figure 3.1: Distribution of household land by farm size................................................... 15 


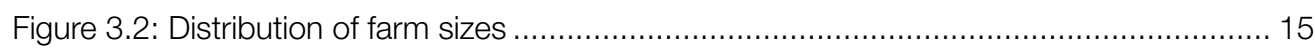

Figure 3.3: Cocoa yields by plot Figure 3.4: Cocoa yields and size of plot......................... 20

\section{Boxes}

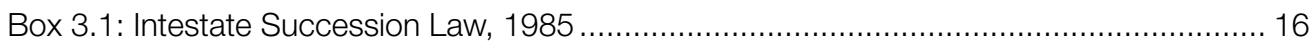

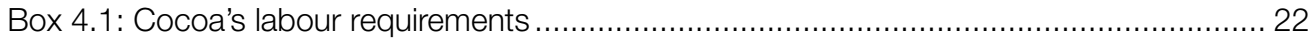

Box 4.2: Toledo the migrant caretaker from Bawku, Northern Ghana.............................. 30 


\section{ACKNOWLEDGEMENTS}

The research team is grateful for the field assistants who helped administer questionnaires and conduct interviews: Dorothy Takyiakwaa, Dzifa Torvike, Alexander Nii Adjei Sowah, Emmanuel Bruku, David Atombire Adumbire, Worlali Torvike and Fobil Ntilam.

We are also very grateful to Ben Michael Awenam and Alex Löwe who helped read and code the qualitative interviews. The research team also appreciates the farmers and others in the Juaboso Municipal who were kind enough to give up their time to respond to our questionnaires and be interviewed. Finally, we wish to thank Stefano Boni and Imogen Bellwood-Howard for reviewing earlier drafts of this paper.

Joseph Awetori Yaro is a professor in the Department of Geography and Resource Development at the University of Ghana. Joseph K. Teye is also a professor in the Department of Geography and Resource Development at the University of Ghana. Steve Wiggins is a principal research fellow at the Overseas Development Institute (ODI), who has been studying and working on agricultural and rural development in Africa and Latin America since 1972.

This working paper is funded with UK aid from the UK government (Foreign, Commonwealth \& Development Office - FCDO, formerly DFID). The opinions are the authors and do not necessarily reflect the views or policies of IDS or the UK government. 


\section{Motivation and purpose}

When in the 1880s farmers in southern Ghana began to plant cocoa, their main concerns were finding land to plant and mobilising labour to do so. The issue of finding land remained paramount until at least the 1990s, when the land frontier of forest to clear for cocoa finally closed. The last forests to be planted were in the old Western Region and particularly in Sefwi, now the Western North Region.

This paper examines how farmers in Sefwi obtained land and mobilised labour in the late 2010s, and how that has changed since the 1960s.

Specifically, the paper aims to:

i. record how land and labour for cocoa were obtained in 2019;

ii. describe changes in land and labour institutions, setting them within the context of changes to the local natural environment, the local economy and society; and to

iii. assess the implications of the changes seen.

\section{Methods}

The results of this paper emerged from a broader study of cocoa farming in Sefwi. That meant that the research had to explore a wide range of factors that influence cocoa growing - ecology and agronomy, society and economy and public policy. Our approach prioritised the experience of farmers and their accounts of their lives as cocoa farmers. Research was qualitative, consisting of semi-structured interviews and discussions held with 65 farmers, labourers, purchasing clerks and extension officers. Additionally, we asked twelve elderly farmers to recount their life histories. We also convened nine focus groups with men and women farmers.

We supplemented this by a questionnaire survey of 276 farmers sampled from five communities in Juaboso Municipal. The survey asked farmers about land tenure and changes, use of inputs, output of cocoa, and government services.

\section{The findings}

\section{Land: the new norms}

Land in Sefwi is held by the chiefs on behalf of the community. Before the 1960s, the population was low and forest lands were abundant. Chiefs would readily grant land to farm to both locals and strangers, the latter paying a small annual ground rent.

Since then, the population has risen, forest has been cleared and some of it has been declared as reserves, so that by 2019 there remained little or no new land to allocate. Farmers now get land either through inheritance under matrilineal or patrilineal norms; by abunu sharecropping where a tenant plants a cocoa farm which is then divided between the tenant and landlord when the trees produce fruit; and by land sales.

In all cases, land users need to square their rights with the local chief, with family and lineage, and sometimes with the state as well. Payments, rituals with witnesses, and documentation confirm rights.

Land, once vested in the lineage and held on behalf of the (very) extended family, with inheritance down the matrilineal line through the mother's brother (wofa), has given way to land controlled by the nuclear family, passed down the paternal line. Although this breaks longstanding Akan custom, it has taken place with little social rupture.

Matrilineal inheritance was progressively challenged by men who had cut land from the forest, or bought it, and claimed individual rights, to be passed on as they chose. They often passed land on as gifts to their wives and offspring in their later years to forestall matrilineal inheritance. In the last two or three decades, most land has been passed down along paternal lines from one generation's nuclear family to the next generation's nuclear family. Little resistance to this from elders or chiefs was apparent.

At the same time, it seems the rights of girls to inherit land have increasingly been recognised. While women farmers interviewed had less land than their male partners, they did have land - either inherited from their father, or shared with them by their husband. 
Is access to land equitable? No, the Gini coefficient of equality of land access was 0.56, which is high. However, land is not being monopolised. Some farmers have more land than others because their family were present when the forests were handed out to farm. These farmers received large allocations - tens of hectares and rarely took over other people's land. The life histories showed large holdings being dissipated by sharecropping, sales and division among offspring, not accumulating. Those who had increased their holdings through time, started from having little or no land, so that their 2019 holding was modest.

Social tension over land was focused not on some people having more than others, but on inheritance. Land disputes, of which relatively few were recorded in the interviews, were almost always either the result of a division of land among the offspring of some deceased male owner that left someone aggrieved that they had not got their rightful share, or the result of widows who had lost land to the extended family when their husbands died.

Youth were disgruntled that there was little land to inherit and that their parents were not giving them land. Youth grievances, however, were somewhat muted, since it was clear, by word and deed, that many did not wish to become farmers. They were not studying in tertiary colleges and universities, taking up apprenticeships, or joining with friends to buy a taxi, to become farmers. On the contrary, their dreams were urban.

\section{Was land distribution efficient? Did distribution lead to cocoa lands being used productively?}

Inefficiencies could be seen among farmers lacking labour: elderly farmers could not work and their children had long left home and farmers on low incomes who could not afford to hire. In some cases, they had let their cocoa plots go fallow, growing some food crops among the untended trees. Unproductive plots may be defined as those with yields of less than $312 \mathrm{~kg}$ per hectare. Out of 560 plots, 210 (38 per cent) were yielding less than $312 \mathrm{~kg}$.

That, however, overstates allocative inefficiency. Many of the 210 low yielding plots were technically inefficient: they were old groves that needed replanting, groves suffering the ravages of black pod and insects, or were too weedy, infested by mistletoe, or dying from swollen shoot. Unproductive plots tended to be larger plots. Plot size was inversely related to yield, although weakly so, with a correlation coefficient of -0.23. These inefficiencies stemmed largely from lack of labour or lack of working capital or both. Farmers with low yields knew they could do better but they did not have the ready cash to hire labour or buy inputs, such as the sprays needed to control insects and black pod, when they were needed. Lack of working capital to buy inputs was often associated with pressing demands for cash to pay school fees and meet medical bills.

\section{Labour: new opportunities, old institutions}

In relation to labour, farmers first cultivate using their own, personal labour. However, unless the cocoa grove is very small (under an half an hectare), key tasks such as weeding, harvesting and breaking pods require more labour than one woman or man can provide.

The next recourse is to draw on the rest of the household. Gender norms dictate that tasks such as climbing trees to cut parasites and harvesting pods are men's work, owing to the risks of falling or being hit on the head by a falling pod. A woman working on her husband's land may expect a share of the harvest or a land grant as compensation. Offspring expect land in the future, and some payment for their work.

While the institutions governing the availability of labour did not change, the degree to which farmers used them did. Farmers used less labour from their family and exchange labour groups declined, being limited to small groups that worked collectively on the hard work of breaking cocoa pods. The use of sharecropping caretakers or caretakers paid an annual fee was uncommon. Farmers increasingly recruited extra labour as hired hands, from gangs being paid piece rates.

Some farmers claimed it was harder to recruit labour than before, owing to competition from mining, from jobs in rural market centres. However, they usually agreed that if you had the cash to pay, you could find labour. Hence, obtaining labour was also a question of capital.

While some observers thus see labour as being commodified, some arrangements only function with significant trust and social affiliation, for example, the farmer who puts up the annual labourer, a youth from the north, in his own house; the Togolese gangs prepared to work and wait until the harvest, trusting the farmers to then pay them for their work; and the farmers who trust their caretakers to share their harvest honestly. These are not the relations of hard capitalism, a gig economy in the forest, but one where personal relations count as much as wages.

Considerations of hiring labour should not be overplayed. Farmers did not use much hired labour: the median days reported in the survey was just 11 days per hectare, with a mean of 15 days per hectare. The bulk of the labour needed to farm came from the farmer and their immediate family. Labour hiring was 
concentrated on the two heavy demands: weeding early in the season and harvesting at the end of the season. Indeed, as cocoa farms become smaller with increasing population, hired labour may be becoming less important.

\section{Women at a disadvantage, even if some improvement has been seen}

Women are usually disadvantaged in both land and labour, typically receiving smaller shares of inherited land than men. When husbands die, men may grab their land under cover of lineage rules. As farmworkers, women are restricted to the lowest paid tasks and their skills are not financially rewarded.

Some of the interviews suggest these inequalities are lessening. Patriarchs are more likely to pass on some of their land to their daughters. Some farmers see that women can carry out tasks seen as skilled and male. Nevertheless, the inequalities remain. It is easier for men to grow cocoa than women.

\section{Conclusions}

We end on a reflection. While Ghana still had a forest frontier on which to plant new cocoa groves, mobilising land and labour that began in the 1880s remained critical to the sector. Today that has ended. No frontier remains: the groves run up to the Ivorian border. That removes one source of profit: the forest rents from newly cleared land.

In the last 70 years, circumstances have changed in Sefwi. The land frontier has closed as forests have been cleared for cocoa and other crops or declared reserves. Family labour has also become scarcer as children go to school and their work in the cocoa groves is restricted by labour laws. Other activities compete for household labour, including crops such as rubber and oil palm, galamsey mining, jobs in local market centres, and migration to the cities. Cocoa farming has become more difficult as groves of old trees (over 30 years old) begin to decline and need replanting, and as pests and diseases increase - especially swollen shoot.

In response, the institutions governing access to land and labour have changed, but gradually, with adaptation and evolution of longstanding institutions rather than transformation and revolution.

Hence the challenge for the farmers of Juaboso Municipal, both Sefwi and strangers, is this: forest rents must be replaced by technical rents. The future lies with technical improvement, and with that, injections of capital. It is no longer primarily about mobilising land and labour. The new agenda invites questions about innovation, about state services, and about farmer access to capital to invest in upgraded cocoa. 


\section{INTRODUCTION}

Since the beginning of cocoa cultivation in Ghana in the 1880s, cocoa farmers have mobilised land and labour to plant trees. Farmers were incentivised by the profits to be made from cocoa - margins that derived partly from the initial natural fertility of the forests of southern Ghana, and partly from the prices paid in industrialised countries of Europe and North America for chocolate cascading down to the price paid for cocoa beans. In the late nineteenth century, growing cocoa promised high returns to semi-skilled labour, offering a way to enjoy more material comforts and to accumulate capital.

The history of cocoa from the early twentieth century in Ghana ${ }^{1}$ has largely concerned mobilising land and labour. From 1936 onwards, land and labour mobilisation have been interrupted by outbreaks of swollen shoot disease. These outbreaks led to early cocoa groves being abandoned and replaced by new groves in the forest to the west. In addition, predatory taxation and a disastrous macroeconomy in the 1970s have disrupted land and labour dynamics. A generation or more of Ghana scholars have thus been fascinated by how land and labour have been recruited to cocoa, most notably Hill (1963). ${ }^{2}$ In the 1970s and 1980s, attention shifted towards problematic policy, only to return to land and labour once dysfunctional policy was largely corrected by Rawlings' 1983 reforms, leading once again to producers investing in cocoa (Kolavalli and Vigneri, 2011).

The frontier for new cocoa farms moved ever further west reaching the high forest of the Western Region in the 1950s and 1960s. Chiefs still had forest land that they could allocate both to locals as well as to incomers or 'strangers' wanting to plant new groves.

Since 2000, the Western Region has been producing about half of Ghana's cocoa. The forest is not limitless. Not only has it increasingly been converted to cocoa, the government has also designated blocks of forests as reserves to conserve them. Hence by 2000 the frontier was closing in the high forest of the Western Region. By 2010 few new lands could legally be developed, and by 2019 cocoa farmers and key informants all agreed that the frontier had finally closed.

This paper addresses the following questions:

i. How were land and labour accessed in Sefwi in 2019 ?

ii. How and why has that changed over the last 70 years?

iii. What have been the consequences and significance of these changes?

The rest of the paper first sets out the methodology and data sources used. Section 3 deals with land access, section 4 with labour use, and the final section concludes by synthesising the overall findings.

1 See Amanor, Yaro and Teye (2020) for a more detailed account.

2 See also Austin (2014) and Green (2017). 


\section{METHODOLOGY}

This paper reports on part of a wider study of cocoa farming in Sefwi that aimed not only to examine land and labour, but also the changing prospects for growing cocoa and the challenges facing farmers. Because the questions were broad, a wide array of data were collected and the views of the cocoa farmers themselves were prioritised. We could have set tighter questions, perhaps with hypotheses to test, but to do so would have risked biasing the data towards our own perspectives and interests and not allowing the farmers to talk about what concerns them.
In this study we therefore adopted a mixed methods design. Qualitative enquiries were devised to hear the voices of the farmers and of those working with them, including extensionists and purchasing clerks. A survey of cocoa growing households was carried out to understand the frequency of the observations reported in the interviews and to measure outcomes.

A reconnaissance in late 2019 preceded the main study and involved four focus group discussions (Figure 2.1), interviews with two chiefs, and interviews with ten

Table 2.1 Qualitative methods showing the number of interviewees

\begin{tabular}{|l|c|}
\hline Life histories & 12 \\
\hline Individual interviews & 54 \\
\hline Farmers & 5 \\
\hline Labourers & 4 \\
\hline Purchasing clerks & 2 \\
\hline Extension officers from the Cocoa Disease and Pest Control Programme & 2 \\
\hline Chiefs & 9 \\
\hline Focus group discussion & $\mathbf{8 6}$ \\
\hline Total qualitative interviews & \\
\hline
\end{tabular}

Source: Authors' own

Figure 2.1: Focus group discussion held during the reconnaissance survey in Juaboso Nkwanta

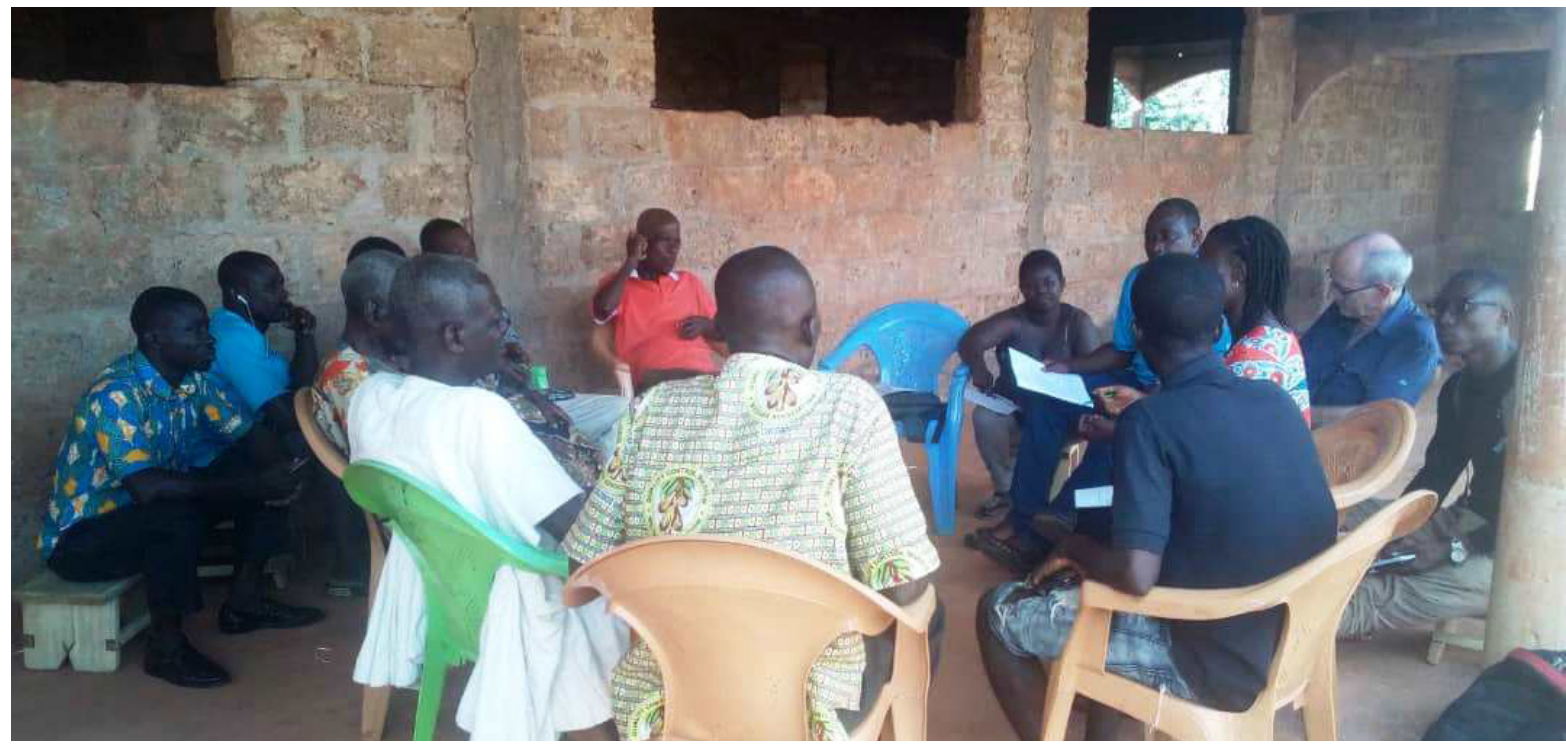

Source: Authors' own 
farmers in two communities: Juaboso Nkwanta and Abrokofe which represent an old and young cocoa growing community in the district.

For the main study, five communities from Juaboso Nkwanta and Abrokofe were chosen (Figure 2.2). Data were collected in the field for three months beginning in November 2019.

Qualitative enquiries (Table 2.1) included interviews with individual farmers, purchasing clerks and labourers, cocoa extensionists and chiefs, life histories of elderly farmers and separate discussions with groups of male farmers and groups of female farmers.

To establish a historical account, we also reviewed older literature.

Based on insights from the preliminary analysis of the qualitative data from the reconnaissance study, a structured questionnaire was designed and used to collect largely quantitative data from five farming communities.
For the household survey, systematic sampling was used to select 276 farmers from five communities (Table 2.2). The sample size in each of the five communities was proportional to the population. In each community, the estimated number of the houses was divided by the pre-determined sample size to obtain the sampling interval used to select the houses to participate in the study. Trained enumerators and their supervisors walked from one end of the community to another and selected houses that would participate in the study according to the sampling interval. One farmer was interviewed in each selected house. Where more than one farmer lived in a selected house, established sampling protocols were followed to ensure that farmers represented age and gender groups. The questionnaire sought to obtain information from farmers on temporal changes in land tenure arrangements, use of inputs, output of cocoa, profitability of cocoa farming, and government policies. STATA and Excel were used to analyse quantitative data.

Figure 2.2: Juaboso Municipal District, Western North Region, with study site

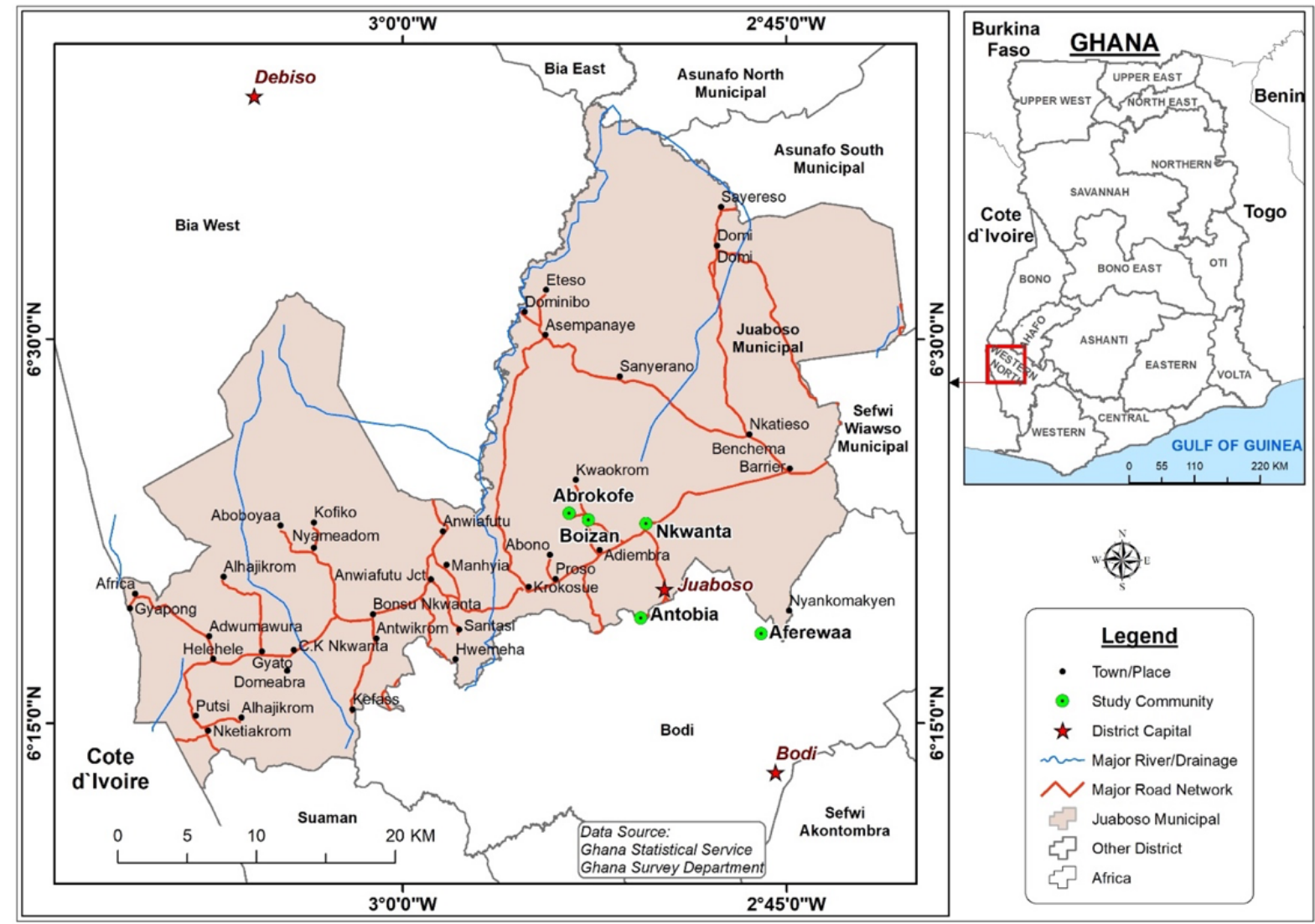

Source: @ Ghana Statistical Services, adapted by authors 
Table 2.2. Number of survey respondents in sampled communities

\begin{tabular}{|l|c|c|c|}
\hline Community & Male & Female & Total \\
\hline Juaboso Nkwanta & $43(25 \%)$ & $23(22 \%)$ & $56(24 \%)$ \\
\hline Abrokofe & $36(21 \%)$ & $20(19 \%)$ & $50(19 \%)$ \\
\hline Antobia & $27(16 \%)$ & $23(22 \%)$ & $52(19 \%)$ \\
\hline Aferiwa & $33(19 \%)$ & $19(18 \%)$ & $52(19 \%)$ \\
\hline Bonzai & $33(19 \%)$ & $19(18 \%)$ & $\mathbf{2 7 6}(\mathbf{1 0 0} \%)$ \\
\hline Total & $\mathbf{1 7 2 ( 1 0 0 \% )}$ & $\mathbf{1 0 4}(\mathbf{1 0 0 \% )}$ & \\
\hline
\end{tabular}

Source: Authors' own 


\section{ACCESS TO GOCOA LAND IN SEFWI}

\subsection{Changing land relations from the 1930s}

From the 1930s when a few migrants started establishing cocoa farms in Western Region, land was given out freely by chiefs for a token fee called aseda (Hill and McGlade, 1957). Most indigenes preferred to grow food crops for family subsistence and some may not have been aware of the returns to planting cocoa.

Society was organised by lineages that controlled land allocated by chiefs and transferred land matrilineally according to lineage norms. ${ }^{3}$ From the 1950s, however, as cocoa boomed, several individuals and their families cleared huge lands under individual titles which they then transmitted patrilineally (Boni, 2005).

By the 1970s, chiefs, seeing the chance to make money, declared their singular right to allocate remaining forests to migrants through sales, renting and sharecropping. This greatly limited indigene access and rights to virgin land. Indigenes who had already cleared forest lands could sell off their lands to incoming farmers. Purchase thus became an important means to acquire land for migrant and local farmers with money. Migrant farmers were, however, still obliged to pay chiefs an annual rent of a tenth of cocoa produced - the same value as the 10 per cent taxes imposed by the Nkrumah regime in the 1960s.

According to elderly participants in group discussions, migrants in the past could access land for free in these communities without any charge:

'because of the love that was existent in the world in the early days when I was a kid, we didn't take anything from anyone who came around and wanted land. Today the land is divided and each family has its own. We all had our lands that we were farming on and so we used to give land to people who came to us to host them. We gave them these lands to farm on and cater for themselves. That has resulted in the expansion of the community because there is an adage that foreigners are often needed to expand a community'.

(Elderly man at a focus group discussion, Juaboso Nkwanta)

As land became scarcer over time, allocation of land to strangers was no longer free, but subject to sharing of land between the original holder and the tenant, under abunu (halves) contracts. In these, the tenant would plant and establish the cocoa farm, then when the trees began to fruit, the farm would be divided in half between landowner and tenant, for the lifetime of the trees or longer (Knudsen, 2007).This arrangement has endured, albeit with changes to length of tenancy and the circumstances under which land can be taken back - a neglected farm or one where the cocoa has died without replacement is liable to be repossessed.

Takane (2002) argues that abunu $u^{4}$ transfers of land in exchange for labour were a gain by labour against landowners. Because most migrants had no means to buy land, sharecropping - perhaps better termed share-tenancies - has been a key means to obtain land, just as it was in regions to the east. ${ }^{5}$

By the end of the 1970s, many landowners unable to establish cocoa farms for lack of labour or capital, who now realised the economic returns to cocoa, invited sharecroppers to establish cocoa farms on their land. Land sales thus declined drastically in the 1980s and are currently limited to few desperate sales.

The neoliberal era, from the late 1980s, saw insecurity for migrants whose lands were threatened by reinterpretations of cultivation rights, forcing many to seek re-documentation from higher chiefs at a

$3 \quad$ Matrilineal norms dictate that a woman's sons will inherit land not from their father, but from their uncle - their mother's brother.

$4 \quad$ Also termed yemayenkye: do and let's share.

$5 \quad$ Arhin (1988) describes how only a few migrants were able to purchase land outright, while the majority accessed it on sharecropping terms or had to pay ground rent to their landlords (ground rent was called 'nto'). 
cost. The length of tenure on land acquired through sharecropping, initially in perpetuity subject to annual rents, was commuted to the lifetime of the trees (Boni, 2005).

Changes have taken place to the inheritance of land as well. Nuclear families have struggled against matrilineal norms that vest rights in the extended family or lineage, in favour of patrilineal norms where the male head of household can pass on land to wives and offspring (Bukh, 1979, Grier, 1992). Land grants have long been seen as fair reward to wives and children for their labour in establishing cocoa farms (Hill, 1963). Struggles over land have led to tenure divided between big landowners of cocoa farms, mostly chiefs and early takers of land from the 1950s to the 1970s; and later entrants into cocoa and commoners who mostly own small, fragmented parcels of land.

Wealth accumulation still hinges mostly on this historical advantage of capturing land earlier and chiefs controlling access to land which gives them further advantage in modern circuits of wealth accumulation. Crook (2001) describes how the colonial administration's support for chiefly control over land created and sustained social differentiation. Table 3.1 summarises land access past and present.

\subsection{Contemporary dynamics in access to land for cocoa in Sefwi}

The household survey showed that vacant lands were non-existent and that people accessed lands previously acquired and owned. In addition, land ownership lay predominantly in the hands of families and individuals.

The survey covered 276 households who operated 569 plots or farms, with most households operating more than one plot. The majority of plots (79 per cent) had been acquired through family: most of them inherited, and the remainder mainly gifted. Fathers were the most frequent plot providers, followed by mothers and grandparents (Table 3.2).

It is striking to see how few plots were obtained through lineage and matrilineal norms: just 9 out of 569 plots. Equally notable is how few plots were purchased or gained through abunu: just 5 per cent for each case.

Table 3.1 Land acquisition in Sefwi: forms and conditions

\begin{tabular}{|c|c|c|c|}
\hline $\begin{array}{l}\text { Type of } \\
\text { acquisition }\end{array}$ & Who qualifies & $\begin{array}{l}\text { Obligations on } \\
\text { tenure holder }\end{array}$ & Rights of tenure holder \\
\hline $\begin{array}{l}\text { Inherited land, } \\
\text { lineage }\end{array}$ & $\begin{array}{l}\text { Relatives of land } \\
\text { holder. }\end{array}$ & $\begin{array}{l}\text { Farm the land. } \\
\text { Respect lineage } \\
\text { custom. }\end{array}$ & $\begin{array}{l}\text { Rights given either matrilineally from the maternal } \\
\text { uncle, or patrilineally from the father. Usufruct rights: } \\
\text { land belongs to lineage: should not be alienated } \\
\text { without lineage consent. }\end{array}$ \\
\hline $\begin{array}{l}\text { Inherited land, } \\
\text { individual }\end{array}$ & $\begin{array}{l}\text { Relatives of land } \\
\text { holder. }\end{array}$ & $\begin{array}{l}\text { Farm the land. } \\
\text { Respect (immediate) } \\
\text { family. }\end{array}$ & $\begin{array}{l}\text { Rights given by a parent or family head, usually male, } \\
\text { to their offspring. May be gifted to offspring during } \\
\text { the parent's life or passed on to them on death of the } \\
\text { parent. }\end{array}$ \\
\hline $\begin{array}{l}\text { Freehold } \\
\text { grants by local } \\
\text { chiefs }\end{array}$ & $\begin{array}{l}\text { Indigenes only. Mainly } \\
\text { before the1970s. }\end{array}$ & $\begin{array}{l}\text { Holder must clear } \\
\text { forest and farmland. }\end{array}$ & $\begin{array}{l}\text { Land held in perpetuity. Some owners can allocate } \\
\text { land as individual land to wives and offspring. }\end{array}$ \\
\hline $\begin{array}{l}\text { Leasehold } \\
\text { grants by local } \\
\text { chiefs }\end{array}$ & $\begin{array}{l}\text { Migrants. Mainly before } \\
\text { the1970s. }\end{array}$ & $\begin{array}{l}\text { Clear forest and } \\
\text { farmland. Pay small } \\
\text { annual ground rent } \\
\text { (nto) to (local) chief. }\end{array}$ & $\begin{array}{l}\text { Land held while the holder is alive. Inheritance is } \\
\text { ambiguous. }\end{array}$ \\
\hline $\begin{array}{l}\text { Land sales } \\
\text { by chiefs, } \\
\text { landowners }\end{array}$ & $\begin{array}{l}\text { All. Mainly since the } \\
\text { 1970s. }\end{array}$ & Pay the price of land. & $\begin{array}{l}\text { Land held in perpetuity. Some owners can allocate } \\
\text { land as individual land to wives and offspring. }\end{array}$ \\
\hline $\begin{array}{l}\text { Sharecropping } \\
\text { or share- } \\
\text { tenancies with } \\
\text { abunu split }\end{array}$ & All. Since the 1970s. & $\begin{array}{l}\text { Clear forest and farm } \\
\text { until groves are well } \\
\text { established, 4-5 } \\
\text { years. }\end{array}$ & $\begin{array}{l}\text { Tenant can grow food crops while cocoa matures. } \\
\text { Once cocoa farm is established, split 50:50 abunu } \\
\text { between landowner and tenant. }\end{array}$ \\
\hline
\end{tabular}

Source: Authors' summary of information from both household survey and from interviews and discussions with farmers 
It seems, then, that longstanding norms of matrilineal inheritance and lineage ownership have all but disappeared, to be replaced by land passed down the generations within the nuclear family. Birth is the main determinant of land access, with few willing or able to buy land or gain it through sharecropping.

Figure 3.1 and 3.2 demonstrated that land ownership was uneven. Male farmers owned more land than female farmers with an average of 14.7 acres [6ha] versus 8.7 acres [3.5ha]. The distribution of land across households showed that most households owned fewer than 20 acres [8ha] (Figure 3.1) with a mean holding of 12.5 acres [5ha], median of 10 acres [4ha], and an interquartile range spanning 5 to 15 acres

Table 3.2: Source of plots

\begin{tabular}{|c|c|c|c|c|c|}
\hline & Family land & Other & Purchased & Sharecropped & Total \\
\hline Inherited & 287 & & & & 287 \\
\hline Father & 162 & & & & 162 \\
\hline Grandparent & 25 & & & & 25 \\
\hline Head of lineage & 2 & & & & 2 \\
\hline Mother & 86 & & & & 86 \\
\hline Mother's brother (Wofa) & 1 & & & & 1 \\
\hline Other & 3 & & & & 3 \\
\hline Spouse & 8 & & & & 8 \\
\hline Gift & 148 & & & & 148 \\
\hline Father & 43 & & & & 43 \\
\hline Grandparent & 32 & & & & 32 \\
\hline Head of lineage & 1 & & & & 1 \\
\hline Mother & 49 & & & & 49 \\
\hline Wofa & 4 & & & & 4 \\
\hline Other & 9 & & & & 9 \\
\hline Spouse & 10 & & & & 10 \\
\hline Abunu & 5 & & & & 5 \\
\hline Father & 1 & & & & 1 \\
\hline Mother & 2 & & & & 2 \\
\hline Other & 2 & & & & 2 \\
\hline Abunu & 2 & & & & 2 \\
\hline Father & 1 & & & & 1 \\
\hline Mother & 1 & & & & 1 \\
\hline Other & 5 & & & & 5 \\
\hline Father & 3 & & & & 3 \\
\hline Head of lineage & 1 & & & & 1 \\
\hline Spouse & 1 & & & & 1 \\
\hline [not known] & & 63 & 31 & 28 & 122 \\
\hline Total & 447 & 54 & 31 & 28 & 569 \\
\hline
\end{tabular}

Source: Authors' own, survey data 2019
[2 to 6ha]. A long tail was observed in the distribution (Figure 3.2) with five households owning more than 20 acres [8ha], with a maximum of 200 acres [81ha]. Owing to this long tail, the Gini coefficient for land is 0.56 , indicating highly unequal land ownership. Half of the cocoa land was in the hands of 58 households, while the other half was spread across the other 218 households.

\subsubsection{Inheritance of cocoa farms}

The results from the focus groups and the survey showed that land was inherited under two norms: matrilineal inheritance or patrilineal inheritance.

Traditionally, land inheritance in Sefwi occurred 
matrilineally. Beneficiaries received land from their mother's brother, their uncle.

This norm, however, is weakening in favour of patrilineal norms. For example, one focus group participant explained:

'Since we are a matrilineal society, if my mother owns land it also belongs to her daughters. But depending on the individual family decisions, parents can decide to hand over their lands to their male, female or all children'.

(Female cocoa farmer at a focus group discussion in Abrokofe, November 2019)

Matrilineal inheritance was seen as a major hurdle to young people taking over farms. Young people who have laboured for years on their parents' land were loath to see this pass to their cousins, increasingly refusing to work for free on family land.

Patrilineal inheritance, on the other hand, occurs if the lands in question are deemed to be held not by the extended family and hence by the lineage, but by the individual.

Passing on of individually owned lands to children is easier and less complicated than family-owned lands which are often rife with conflicts. A farmer recounted: 'my grandfather gave the farmland to my father and my father passed it down to me' (42-year-old male cocoa farmer from Abrokofe, November 2019). Similarly, a female farmer recalled:

'The first land was given to me by my father and the other land was given to me by my grandfather. With my grandfather's land, it is a

Figure 3.1: Distribution of household land by size of farm

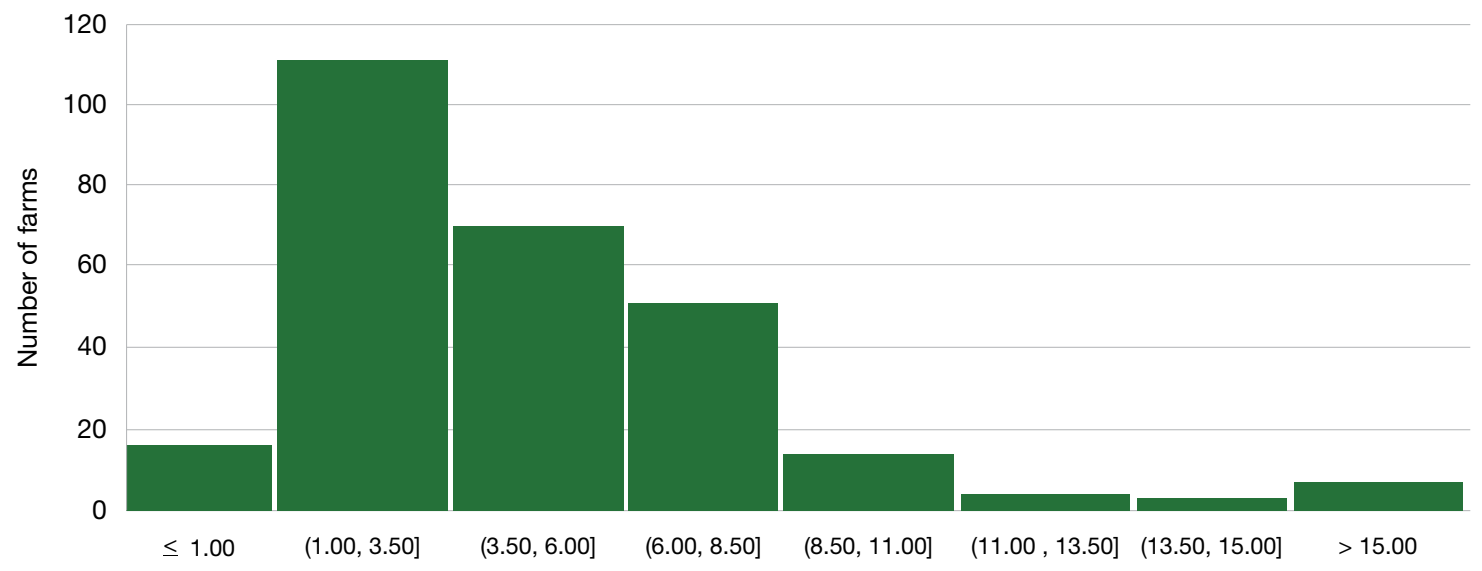

Area of cocoa, ha

Source: Authors' own, survey data 2019

Figure 3.2: Distribution of farm sizes

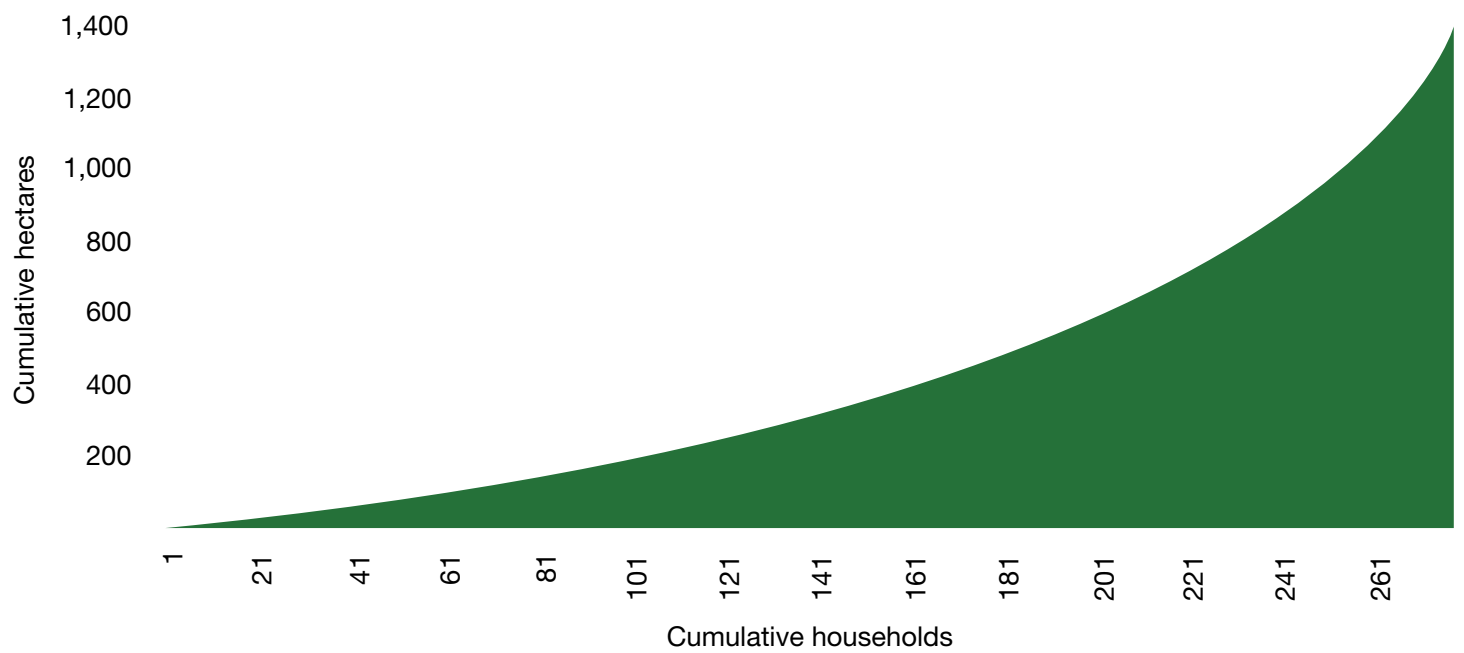

Source: Authors' own, survey data 2019 
long-held family land which dates as far back as my great grandfathers. They kept handing it down when they died, and it has gotten to my turn. I am not the only grandchild that received portions of that farm. It was shared amongst all the grandchildren and that was what I received'.

(Female cocoa farmer from Abrokofe, November 2019).

According to focus group discussion, individual inheritance is normally only possible where the parent owned the said land. Family lands cannot be handed down to children except where the family head decides with the consent of all to share family land out thereby individualising the subdivided lands. This must be consummated by the right rituals to signify individualisation and subsequent patrilineal succession.

Specific rites are performed by the successor in the presence of witnesses to signify the transfer of ownership from parents or grandparents to the child when owner is still alive. When the owner dies intestate, tradition applies, so the head of the lineage in consultation with elders decides on how farms are shared.

Transfers of family lands to individuals may be contested and brought under matrilineal norms if the wife and children are not able to defend their rights using their social capital.

Family members increasingly acquired family lands from the family pool through the performance of rites involving payments, drinks and witnesses to individualise such lands. For example, one female farmer stated:

'My father handed over a secondary forest to me to use as a cocoa farm. The land belonged to my father's family and he happened to be the family head so he gave me a portion to use for cocoa farming. Now that my father has passed away, I would have to meet the family and do the necessary rites by providing some drinks and money to solidify my claim over the land'.

(Female cocoa farmer from Abrokofe, November 2019).

Male focus group discussion participants at Antobia defined an individually owned land as one that was acquired through the clearance of virgin land, that is first occupancy, or that which is purchased. These are the lands that can be willed out and given as gifts.

Patrilineal inheritance seemed to dominate despite serious confrontations with those who want to inherit matrilineally, the orthodox norm. For example, one participant stated:

'We used to inherit [from] our uncles in the olden days. But in 1979, when they were amending the constitution, a lot of people shifted to their patrilineal side. So, they were inheriting from their fathers instead of uncles. When they were inheriting from the matrilineal side, it was not helping us'.

\section{Box 3.1. Intestate Succession Law, 1985}

\section{Provisional National Defence Council Decree, Intestate Succession Law, 1985 (PNDCL 111)}

Establishes what happens to land when the holder dies without clearly indicating to who the rights should be transferred. The law sets out what happens under different conditions, namely: [numbers are sections of the Law]

5. Intestate survived by spouse and child

6. Intestate survived by spouse only

7. Intestate survived by child only

8. Intestate survived by parent only

9. Devolution of residue where customary law is inapplicable

10. Where customary law provides for succession by family

11. Intestate survived by neither spouse, parent nor child

The law also protects the rights of surviving spouses against eviction, and to a house on property and defines how rights will be divided if there is more than one legitimate claimant. 
(Focus group discussion with male cocoa farmers, Antobia, November 2019).

The Intestate Succession Law, presented in Box 3.1, has a wider application in the community as the female focus group indicated that many widows resort to the courts to defend their stake in their husbands' cocoa farms. They also indicated that some chiefs also adjudicated cases using the principles of this law. In their study of land tenure in cocoa growing areas, Quaye et al. (2014) also noted the widespread use of the Intestate Succession Law and the declining influence of matrilineal inheritance which they attribute to all available lands having been duly allocated to the various inhabitants. Inheritance of cocoa farms as property is rife with conflicts as family heads contest the legitimacy and rights of spouses and children to inherit these properties.

Typically, families still appoint a successor to oversee the sharing of the properties of the deceased which is a concern for many wives and children. The quotes below from the youth focus group discussion illustrate these concerns:

'Traditionally a successor is selected to take over the affairs of the deceased and that is also one of the reasons the youth have not been able to make their own farms. My parents have cultivated a farm but the family ends up giving it to someone else to control. Sometimes they - the uncles and family head - can even take the entire land from the widow and her children'.

(M2 speaking at a youth focus group discussion at Juaboso Nkwanta, November 2019).

'Ideally the farm should go to the widow and her children. But just as my brother said, the family of the deceased will select a successor who might be lazy and will take everything that the deceased has reserved for his widow and children. Sometimes it becomes a dispute between the families and some of the successors end up killing the widow so that they can lay claim to the farm. The children might be young and wouldn't be able to fight back when their mother dies'.

(F4 speaking at a youth focus group discussion at Juaboso Nkwanta, November 2019).

These conflicts with successors are common, especially where the deceased has not transferred ownership or shared his farms before dying. Hence many prefer to pass their land on to heirs as gifts, using traditional ceremonies to legitimise transfers, to avert abuse by successors.

\subsubsection{Cocoa land gifted to family members}

Related to inheritance were cocoa lands gifted by parents and grandparents to spouses and offspring When women helped their husbands to establish cocoa farms their husbands could reward their efforts by gifting them a portion of their cocoa estates. This practice has been described by Hill (1963) but seems to be rising in popularity with widespread acceptance by local traditions and norms supported by laws. A 52-year-old lady asserted that:

'As for the land from my husband, it was given to me as a gift in the presence of witnesses. I paid the traditional fee for the witnesses. We even made a document as further security so no one can challenge or take the farm when he or I die'.

(Female cocoa farmer from Abrokofe, November 2019).

Similarly, another woman stated that:

'The land belonged to my late husband so he gave it to me as a gift before he died. That land is an acre and a half in size and so the land and the cocoa on it belong to me now'.

(70-year-old female cocoa farmer from Abrokofe, November 2019).

To finalise such arrangements a thanksgiving rite is often performed with the approval of the family members, usually in the presence of witnesses to signify the land has been handed over to the beneficiary. Similar to inheritance, only individually owned lands can be gifted.

\subsubsection{Sharecropping for land: Abunu system}

Sharecropping used to be a major strategy used by migrants to access lands. Current sharecropping land can be fallow land, a dying cocoa farm or conversion of land from another crop such as oil palm to cocoa. One female farmer explained a typical situation that leads to abunu sharecropping:

'It is a situation where the land is yet to be cultivated with cocoa because the landowner does not have the energy to undertake farming activities and so the tenant farmer starts the farm all by him/herself until it matures. In this situation the farm is divided in two between farmer and landowner'.

(Female focus group discussion, Abrokofe, November 2019).

From focus group discussions, landowners typically give out lands to the tenant sharecropper to establish 
the cocoa. In the first one to five years the tenant grows food crops such as cocoyam, plantain and maise in between the cocoa seedlings - food which is either consumed by the tenant alone or shared with the landowner. Once the cocoa starts fruiting, at between three and five years for the hybrid variety, the farm is divided into two, the landlord makes his preferred choice, an agreement document is prepared, and two or more witnesses and drinks including money are presented to seal the deal. The chief of Sefwi has decreed that all sharecropping arrangements should be 50 years. However, when the cocoa dies, the landowner reserves the right to take back the land or negotiate a new deal. Tenants need to keep cordial relationships with the landlord to avert early repossession of the land.

The agreement documents can be signed at different levels depending on the resources of the tenant farmer and the level of security desired. Hence, the landowner, community chief and Sefwi Overlord (Omahene) sign and finally the state registration system or court signs to seal the deal. In some cases, the documents are prepared only after the cocoa starts fruiting and not at the initial transaction.

Only 11 per cent of the 28 sharecropping arrangements reported in the household survey were documented. Female farmers were less likely to have documents covering their sharecropping arrangements, although this gender difference was not significant

\subsubsection{Purchased cocoa lands and farms.}

Our in-depth interviews showed that lands for cocoa farming can be bought by interested individuals from chiefs, clan heads, family heads and individuals. A price is agreed, and documentation involving surveyors, chiefs and the courts are drawn up. About 80 per cent of males and 86 per cent of females who purchased land had documents to cover the purchase: an improvement over the situation several years ago whereby land purchases were largely covered by verbal agreements. The prices of land are not fixed. People sell lands when they are mostly in need or are having trouble maintaining a diseased farm. Prices for land depend on the landowner, reasons for sale and the demand from competing uses, especially smallscale mining. Miners are often willing to pay higher prices than farmers for land. According to the chief of Juaboso Nkwanta, two decades ago chiefs still had some secondary forest which they could sell to migrants, but these are no longer available.

Land sales are less common than they were. Many interviewees reported owning land bought for them by their grandmothers, grandfathers and parents. Fewer people are now willing to sell cocoa lands since they want to protect them for their progeny. One elderly interviewee indicated that during the 1980s cocoa farms were traded more easily than now, which he attributed to the economic conditions of the time and the value people assign to cocoa farms today as property.

Land purchase was seen by many as the most secure tenure because it is mostly backed by legal documents (see Table 3.3), sealed by traditional rites, and recognised by different stakeholders such as chiefs, family heads, and the state.

Parents often invested in their children by buying cocoa farms for them. For example, one couple in Juaboso Nkwanta purchased a four-acre [1.62ha] cocoa farm for their son. Another female interviewee spoke about investing in land for her son:

'I even bought a land at Bono 10 years ago so he (son) can start a farm there, but he declined...। tried to convince him a couple of times but he declined. Later on, he changed his mind....he was a driver, he bought the car....sold it and we bought a cocoa farm that was already prepared for GHC1,500 [US\$250 at current rates]'.

(Life history: Elderly woman at Abrokofe, November 2019).

She subsequently convinced her husband to buy more land for the children since she was never gifted land from her husband or benefited much from his cocoa farms. Her story mirrors other parents' stories, especially grandparents who want to establish their beloved grandchildren in cocoa.

Table 3.3 The proportion of land sales with documents by gender for Juaboso

\begin{tabular}{|l|c|c|c|}
\hline & Male & Female & Total \\
\hline Document available & $19(79.2 \%)$ & $6(85.7 \%)$ & $25(80.65 \%)$ \\
\hline No document & $5(20.8 \%)$ & $1(14.3 \%)$ & $6(19.35 \%)$ \\
\hline Total & $24(100 \%)$ & $7(100 \%)$ & $31(100 \%)$ \\
\hline \multicolumn{2}{l|}{} \\
\hline
\end{tabular}

Cases observed in household survey, with shares of total in brackets.

Source: Authors' own, survey data 2019 
Compared to the past, lands are now purchased from individuals rather than chiefs. About 93.6 per cent of those who purchased lands reportedly bought them from individuals while just 6.4 per cent bought their lands from the chiefs. However, it is chiefs and rich cocoa farmers who have more 'individual' lands to give out or sell.

Land sales occur when poor families sell small parcels of land with dying cocoa they cannot maintain; when big landowners who are old cannot maintain their farms; when families need money to diversify their income portfolios or educate children (especially at tertiary level) or undertake a major investment; and when, family heads, in consultation with members, decide to sell part of the family land to meet a family contingency.

A rich sub-chief in Juaboso Nkwanta described how he sold his smaller parcels of cocoa that were in other surrounding communities because old age prevented him from managing the full 77 acres [31ha] he owned. Many large landowners have cocoa farms dotted in several places. These landowners, depending on their wealth, may sell smaller and less productive cocoa farms while keeping productive and larger ones.

Sales of cocoa farms therefore occur both out of necessity and choice representing dropping out of cocoa farming or accumulating cash income for other activities as in stepping out. Dropping out of cocoa farming involves a diversification away from cocoa. Poorer farmers dropping off is out of necessity due to disease, poor yields or other desperate sales, while for richer farmers the identification of better investment opportunities may lead to this.

\subsubsection{Land insecurity}

Land tenure insecurities are not new in Sefwi as farmers, both indigenes and migrants, face different insecurities in land relations with patrons. Some migrants' lands were threatened by reinterpretations of cultivation rights forcing many to seek re-documentation from higher chiefs involving more cost. The length of tenure, initially in perpetuity provided annual rents were paid (Boni, 2005), is being cut especially on land acquired through sharecropping. The introduction of the Sefwi customary land secretariat in the 2000s has also come with newer rules, seeking to exact higher rents, reduce tenure periods and even change age-old contracts.

Also, increasing tensions between families seeking to interpret generational transmission of lands using matrilineal and patrilineal or family versus individual systems are rife. Land grants to wives, children and nephews and nieces have always been contested and resisted by families and matrilineal successors (Bukh, 1979; Grier, 1992).
These tendencies are exacerbated under current conditions of customary land management powers granted to chiefs and the resort to modern interpretations of inheritance rather than traditional ones.

\subsubsection{Changes and continuities in land relations}

In sum, the results of the study indicate the following changes in land relations:

i. emergence of serious land scarcities;

ii. inheritance as a major means of land access increasingly from parents to children, posing significant challenges to matrilineal systems;

iii. increasing security of land rights for wives and children;

iv. sharecropping not being as common as before but a route used by both indigenes and migrants thereby posing stiff competition to migrants;

v. documentation of land transactions being much more common today than in the past when witnesses were enough to seal deals;

vi. the operation of customary land secretariats, especially in the Sefwi kingdom, which have formalised transactions which may make them easier to deal with in court compared to the protracted court cases of the past;

vii. sharing of family lands and their subsequent conversion into individualised property;

viii. land fragmentation with unviable farm sizes among poor family members;

ix. and land prices defined mainly by competing interests such as mining and rubber plantations.

The landscape of cocoa farms still maintains the 1970 social structure of big landowners of cocoa farms who are mostly chiefs and early land grabbers from the 1950s to the 1970s, while later entrants into cocoa and commoners mostly own small, fragmented parcels of land. Wealth accumulation still mainly hinges on this historical advantage as large farms benefit more from state support, have capital to invest in intensification measures and can diversify into more lucrative economic activities. The spread of cocoa has had impactful major social and economic change with changes in the conception of the value of land, and new forms of land ownership (Sutton, 1983).

\subsubsection{Efficiency and equity in land distribution}

In relation to the efficiency of land distribution and whether cocoa lands were used productively, the results of the survey showed that some cocoa plots 
were unproductive - defined as plots yielding less than $312 \mathrm{~kg} / \mathrm{ha}$. Out of 560 plots, 210 (38 per cent) were yielding less than $312 \mathrm{~kg} / \mathrm{ha}$ (Figure 3.3).

Unproductive plots tended to be larger plots (Figure 3.4). Plot size was inversely related to yield, although weakly so, with a correlation coefficient of -0.23 .

Plots had become unproductive because farmers did not have the labour to cultivate their cocoa groves. This was typically the case for elderly farmers who could no longer themselves work on the farm and whose children had long left home. Unable or unwilling to hire labour, they let their cocoa groves go fallow, growing some food crops among the untended trees. Some of these unproductive plots were, moreover, old groves that needed replanting. Most common were plots that were hit hard by the ravages of black pod and insects, or were too weedy, or infested by mistletoe. Low productivity stemmed largely from lack of labour, lack of working capital or both. Farmers with low yields knew they could do better and knew how to better tend their trees, but they did not have the ready cash to hire labour or to buy inputs, such as sprays needed to control insects and black pod, when they were needed.

Reports of lack of labour to farm was surprising. It was usually possible for farmers lacking working capital to hire labour gangs and pay them after the harvest was sold and they had the cash to pay. It was not clear just why aging farmers, unable to work and whose children were not present to help, would not contract labour to be paid later. This question was not posed directly in the interviews, but some interviewees seemed dismayed by attacks by crop pests and diseases and

Figure 3.3: Cocoa yields by plot

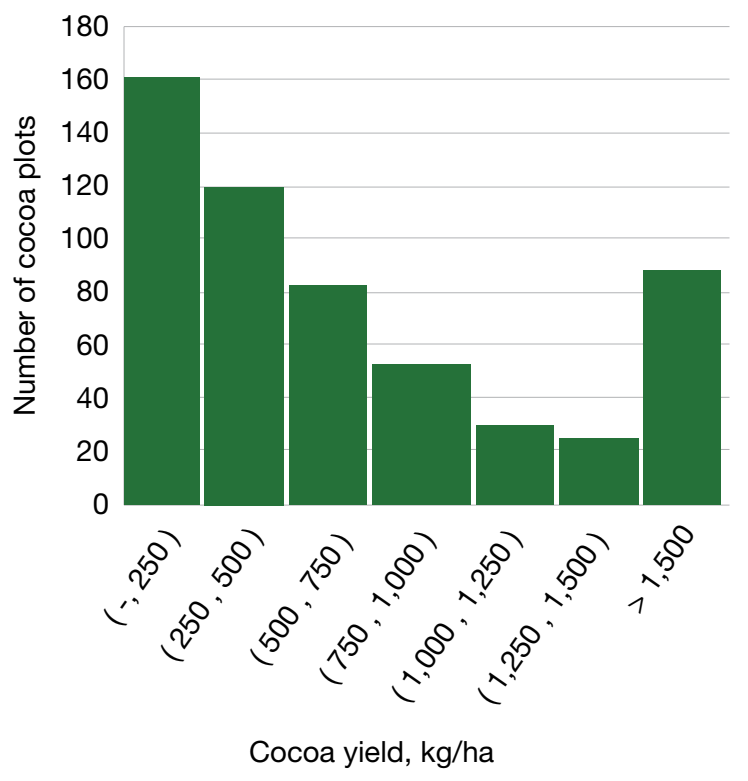

perhaps did not think it worth paying for labour when the effort was likely to produce only meagre returns.

Lack of working capital to buy inputs was more understandable. Farmers had limited income and often faced pressing demands for scarce funds to pay school fees and meet medical bills.

In relation to land access, the Gini coefficient of equality of land access of 0.56 was high, however, land was not being monopolised. Some farmers had more land than others, but Sefwi is not dominated by monopolising landlords who can demand rents from people wanting to farm. Nor is Sefwi inhabited by landless rural households. Some have more land than others because their family was present when the forests were handed out to farm. These families received large allocations. Thus it seems that these large farmers have land due to historical circumstance, rather than through taking over others' land. Indeed, the life histories of elders in Sefwi tended to be ones where a generation ago, the interviewee had more land than they had in 2019. Their lands had been passed down to offspring, or divided among multiple wives, or sold to pay debts. No histories of progressively accumulating large expanses of productive land were heard. Those who had increased their holdings through time, had started from having little or no land, so that their current holding was modest. We did not come across landlords who were renting or sharecropping out large areas say, more than 20 acres [8ha] - and living off the rents.

Social tension over land was focused not on some people having more than others, but on inheritance. Land disputes, of which relatively few were recorded

Source: Authors' own, survey data 2019

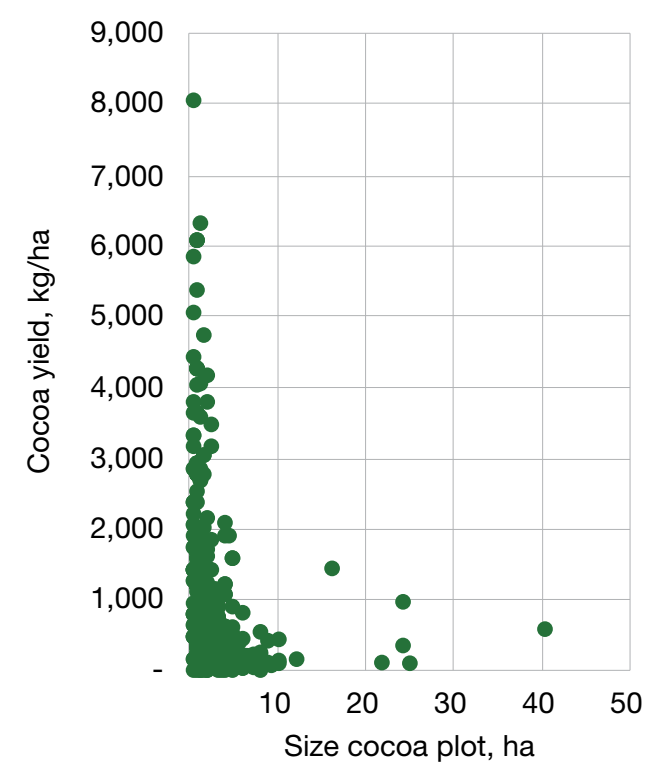


in the interviews, were usually the result of a division of land among the offspring of a deceased male owner that left someone aggrieved that they had not got their rightful share. Land disputes were also commonly related to widows who had lost land to the extended family when the husband died.

At a lower level of discontent, youth were disgruntled that there was little land to inherit and that their parents were not giving them land - a complaint that was particularly heartfelt when the parent had passed their land to a caretaker to farm, rather than their son or daughter. Youth grievances were somewhat diluted, since it was clear, by word and deed, that many did not wish to become farmers. They were not studying in tertiary colleges and universities, taking up apprenticeships, or joining with friends to buy a taxi, to become farmers. On the contrary, their dreams were urban. 


\subsection{Changing labour relations in cocoa production in Ghana}

Cocoa production requires plenty of labour to manage groves well. Cocoa production ideally requires about four weedings per year, removal of mistletoes and other epiphytes, shade management through pruning and removal of basal suckers, application of fertiliser, spraying against pests and disease, and harvesting, opening the pods, fermenting and drying the beans (Dormon et al., 2007) ( see also Box 4.1). Annual requirements per hectare of established trees have been estimated at 136 days (Bray, 1959), 105 days (Urquhart, 1961), and 109 days (Beckett, 1944).

Mobilising this labour has long been intricately related to land access, family relations and scale of production. The earliest cocoa farmers depended upon family labour, with spouses and other members seeing their labour as investment in common property (Okali, 1974; Duncan, 2010). When large cocoa farms were planted in Akim Abuakwa, more labour was needed (Hill, 1963). Some was recruited from the extended family, with land distributed to family members in exchange for labour (Hill, 1959). Some labour was hired from migrants from the Volta area, northern Ghana and Sahelian countries.

By 1910, labour was hired in four ways. One, annual labourers who were paid at the end of the year although this was in decline owing to some farmers not paying up. Two, abusa caretakers rewarded by a third of the crop for taking care of the farm, including pruning, weeding it, and harvesting the cocoa. Both groups also enjoyed grants of food crop land to feed themselves and their families. Three, nkotokoano whereby a labourer-harvester was paid a fixed sum for every bag of cocoa harvested. Four, casual labour engaged to perform varied tasks, paid by day or task (Hill, 1963).

These varying forms accommodated farmers' cash flow: whether hiring farmers had cash to pay labour

\section{Box 4.1 Cocoa's labour requirementst}

'When one acquires a land for cocoa, you need to cut trees, clear undergrowth, and burn it. After which you plant cocoyam, plantain and other food crops which is then intercropped with the cocoa seedlings to provide shade. These crops grow together for three years requiring frequent weeding and other agronomic practices if the cocoa is hybrid, or for five years if it's an older hybrid and Amazonia variety. Benefits are derived from food crops for feeding or sale depending on quantum of harvest.

Without a thorough regime of weeding the farm at least four times annually the cocoa will not grow well. After, husbands, with or without the help of labourers, clear the forest land, their wives normally plant the food crops while the men plant the cocoa. They make boundaries on the farm if he has two wives because he needs to show where each wife and her children will control.

When the trees grow, we need to prune, spray and weed under them. During the harvest, which is normally the major and the minor season, you need harvesters, carriers, breakers and dryers. These can be done using a combination of labour from family, casual by-day labour, abusa caretaker, annual labour caretaker, abunu sharecropper, and labour parties or groups'.

[Focus group meeting with men in Juaboso Nkwanta]

Labour needs vary through time. Planting and establishing a farm require a lot of labour, while maintaining productive trees requires less labour. When cocoa dies or becomes diseased, labour demands increase again to remove the dead or diseased trees and replant. Over the past ten years cocoa production in the Juaboso municipal has come under attack by diseases leading to declining productivity and the need to replant farms, with sporadic and little state support. 
there and then or needed to await harvest before they could pay.

Over time the importance of different forms of labour has changed. Use of labour from the nuclear and extended family has declined, largely because as land has become less abundant farmers have not been able to reward their family helpers by granting them land. Lineage reciprocity and solidarity has been undermined by dwindling spare land (Amanor, 2005). Most recently, child labour has been lost to schooling and labour laws restricting use of children.

Annual contracts and share contracts have become less attractive because once cocoa groves are well established with a full canopy, food crops cannot be grown among the cocoa for lack of light (Sutton, 1983). Hence, casual labour has become increasingly important (Sutton, 1983)

\subsection{Labour forms and dynamics in cocoa farms in Juaboso Municipal}

The results show that farms in Sefwi are worked by a combination of household and hired labour (Table 4.1).)

Most of the time, cocoa farmers in Juaboso work alone on their farms or with their spouses (Table 4.2). Regular hired help comes from sharecroppers, employed by just under a fifth of farmers.

Regular labour is supplemented by additional hands for arduous tasks, such as weeding, and for peak seasons such as the harvest.

In the past, labour was likely to come from the family or from migrants hired on year-long contracts. However, these arrangements are giving way to hiring labour for specific tasks:

'In the past we worked on the farms with our wives and children. But now labourers are gradually replacing or complementing family labour. We have by-day workers and some labourers who work per acre and they are paid accordingly. Other farmers hire labourers who work on the land for a year and they are paid a fixed rate and provided with some other welfare arrangements. Those who work for a year as if they belong to your household (adopted labourers) are fully catered for in terms of feeding, health, inputs, accommodation etc. but they still receive a payment at the end of the year as agreed. Many of these labourers are young migrant men and children, mostly from the north. This arrangement was in existence before this community was established, but

Table 4.1: Forms of labour in Sefwi

\begin{tabular}{|c|c|c|}
\hline Form & Tasks & Payment and conditions \\
\hline Farmer's own labour & All & None \\
\hline $\begin{array}{l}\text { Household labour from } \\
\text { spouse, offspring }\end{array}$ & $\begin{array}{l}\text { All, but women may not cut parasites } \\
\text { from trees or harvest pods because } \\
\text { this is seen as dangerous or male } \\
\text { work. }\end{array}$ & $\begin{array}{l}\text { None, but with promises to transfer land in the } \\
\text { future; or pocket money. }\end{array}$ \\
\hline $\begin{array}{l}\text { Exchange labour - } \\
\text { groups within community } \\
\text { who know and trust one } \\
\text { another }\end{array}$ & $\begin{array}{l}\text { Typically for laborious work, especially } \\
\text { breaking pods. }\end{array}$ & $\begin{array}{l}\text { Obligation to join in with group as it goes around } \\
\text { members' farms. }\end{array}$ \\
\hline $\begin{array}{l}\text { Hired by day - may be } \\
\text { locals or migrants }\end{array}$ & \multirow{2}{*}{$\begin{array}{l}\text { Typically hired for laborious tasks: } \\
\text { weeding, harvesting, breaking pods. } \\
\text { Task rates usually offered when the } \\
\text { job needs doing promptly. }\end{array}$} & $\begin{array}{l}\text { Set local rate paid, typically GHC25 [US\$4.2] a day. } \\
\text { May be a premium for harvesting. }\end{array}$ \\
\hline $\begin{array}{l}\text { Hired by task - most } \\
\text { likely to be migrants }\end{array}$ & & $\begin{array}{l}\text { Paid by measured area, e.g. GHC } 100 \text { [US\$17] to } \\
\text { weed an acre [0.4ha]. } \\
\text { Work carried out by gangs. Migrants from the north, } \\
\text { Volta and Togo commonly work in groups. } \\
\text { Payments may be deferred until after beans have } \\
\text { been sold. }\end{array}$ \\
\hline $\begin{array}{l}\text { Hired: caretakers - } \\
\text { typically young migrants } \\
\text { from the north }\end{array}$ & \multirow[t]{2}{*}{ All } & $\begin{array}{l}\text { Paid an annual fee. The caretaker is also given land } \\
\text { to grow food, accommodation, and medical bills are } \\
\text { paid. }\end{array}$ \\
\hline $\begin{array}{l}\text { Hired: caretakers - may } \\
\text { be migrants or locals }\end{array}$ & & $\begin{array}{l}\text { Paid one third of the value of cocoa at the end of the } \\
\text { season. }\end{array}$ \\
\hline
\end{tabular}

Source: Authors' own 
it is becoming difficult to find such labourers compared to the past'.

(Focus group participant -Juaboso Nkwanta)

The increasing importance of wage labour is a continuation of the process began in the 1920s as described by Hill (1963) and Sutton (1983). Social modernisation and economic liberalisation have played important roles in influencing these changes (Amanor, 2005).

\subsubsection{Family labour}

Household labour, available to almost all farmers in Juaboso, comes from farmers and their immediate relations - usually the nuclear family but can include others domiciled with them. Men were engaged in all stages of cocoa establishment and maintenance, while activities such as weeding, growing food crops and carrying and breaking cocoa pods were reserved for women. When children helped on cocoa farms, they gathered pods, weeded and helped transplant nursed seedlings.

Most male farmers with farms in different communities or even in the same community shared their lands among their wives. The wives managed the farms, supported by their husbands in tasks perceived as men's work. Men often established the farm before handing over to wives. The proceeds or income went to the husband who then provided the material needs of the wife and her children. Cocoa income was mainly in men's hands except where farms explicitly belonged to wives.

For new farms, household labour was used to begin cocoa farming as few farmers had the income to hire labourers:
'I did not have any capital to start with, so I relied on my own physical strength to undertake all the activities on the land'.

(Female cocoa farmer, 52 years, Abrokofe, November 2019).

The interviewee began with an acre [0.4ha] of cocoa, then gradually expanded to six acres in different plots over time. Subsequent farms were more likely to be worked with some hired labour than the first farms.

Mobilising relatives as labour was important for poorer small farmers in dealing with high cost of labour when cash is scarce.

'I do not usually hire labour because most of the time, my siblings and even my mother help in undertaking activities on the farm. It is only when I am going to weed that I usually hire about two labourers'.

(Interview, 27-year male cocoa farmer from Abrokofe, November 2019).

A male farmer at Juaboso Nkwanta with young children, who planted his first cocoa farm in 1992 and now has four farms totalling eight acres [3.2ha] states:

'I don't have money to hire them (labour) so I do the work myself. I do the work with my wife because my children are too young to assist. I hire labourers when I have some money but it is rare'.

(Male farmer, 49 years, Juaboso Nkwanta).

The extended family did not seem to contribute much labour. This may be because cocoa is sold, rather than kept as a communal commodity. The exception are family members outside the nuclear family who are

Table 4.2: Proportion of regular workers on cocoa farms in Juaboso

\begin{tabular}{|l|c|}
\hline & $\%$ \\
\hline Alone & 58.7 \\
\hline With spouse & 34.4 \\
\hline With child & 12.3 \\
\hline With father & 0.4 \\
\hline With mother & 1.1 \\
\hline With other relative & 2.9 \\
\hline With sharecropper & 18.8 \\
\hline With annual sharecropper & 3.3 \\
\hline
\end{tabular}

Source: Authors' own, survey data 2019 
maintained by the household head, who can then ask them to work in return for their upkeep.

Once cocoa trees bore fruit and generated funds, farmers typically hired additional labour, depending on family labour availability and the tasks at hand:

'Basically, it is myself and my wife who maintain the farm but when we find that the work is too much then we hire labourers'.

(47-year-old male cocoa farmer, Abrokofe, November 2019).

Uses of family labour is declining. Family labour is not guaranteed as social modernisation and monetisation of social relations has led to some family members dropping out of the family's pool of labour. Most farmers are losing family labour, especially that of children owing to education and child labour laws. Children are more likely to be enrolled in school, other vocational training, or apprenticeships to acquire certificates, skills and competences needed to diversify from farming.

'One of my children is a tailor in the village, another works in Juaboso hospital as an accountant, another runs a shop at Nkwanta, another is also a tailor at Kroso... there is only one child that stays with me in this town, but not in my household. The last is in Accra learning a trade so I do not stay with them'.

(52-year-old female cocoa farmer, Abrokofe, November 2019).

Most children of cocoa farmers are moving into other livelihoods rather than cocoa farming alone, leading to the use of hired and caretaker labour.

In their absence, the farm is worked by their parents, caretakers or hired labourers.

'My children do not go to the farm regularly due to their education; they only go to the farm when they come home on vacation'.

(Interview with 52-year-old female cocoa farmer from Abrokofe, November 2019).

Increasingly, youth are not working on their parents' farms. They accused some parents of refusing to give them cocoa farms, instead preferring strangers as caretakers:

F4: Some parents are so old and cannot even work on the farm but they will give it to someone else as a caretaker and not us. They will not give it to their children but rather a total stranger will get the farm as a caretaker.
F1: That is true. Some of the parents will say that their children will not take good care of the farm, or they will take all the proceeds and not give some of it to their parents. And that is why most of the parents prefer to give it to someone else other than their children.

M4: We will not accompany (=work) them (our parents) to the farm again because they don't give us some of the income generated from the cocoa.

M1: It is because of our attitude towards them. We are all in need of money. I am sure if I get money, I will certainly buy all the fashionable clothes and I think the same goes for the women. So, the parents know of this and for that reason they will give the land to a caretaker who will manage it and give him his share of the proceeds which will be more than his children will give to him.

(Participants in mixed youth focus group, Juaboso Nkwanta)

Distrust within some families breaks down the ageold use of family labour on cocoa farms where all members benefit from the proceeds of the farm. This has caused conflict when the youth are not happy with migrant labour taking up their jobs and making them strangers in their own families. The involvement of some sons on their fathers' and mothers' cocoa farms is minimal. Given that most children go to school until junior high when most drop out, attachment to the farm diminishes which may cause parents to doubt the ability of their children to manage their farms. Migrants, on the other hand, have often spent most of their lives on cocoa, accumulating a wealth of experience and skills. They may be more trustworthy because they are afraid to misbehave which could lead to abrogation of their contracts. On the other hand, not all caretakers are trustworthy:

F4: Sometimes the caretakers will steal some of the cocoa and hide it somewhere. Your father will not even believe you if you should report it to him. He will tag you as jealous. He will only believe it when he sees it with his own two eyes. So, the relationship between the caretaker and the farmer is sometimes not cordial. But there are others that are cordial and that is because the caretaker is honest and loyal to the farmer.

(Participant in youth focus group, Juaboso Nkwanta) 


\subsubsection{Labour groups}

Farmers may combine to work jointly on each other's farms in rotation. These labour groups or associations seem to be dying, other than among caretakers for harvesting and breaking pods. Many farmers interviewed saw groups to be increasingly ineffective:

'Those groups are not as effective as they used to be some time ago; it could get to your turn and you will struggle to get people to crush your cocoa pods'.

(52-year-old female cocoa farmer, Abrokofe, November 2019)

While mutual labour groups are on the decline, they are still part of harvest groups because this task requires more people. Group members are mainly friends or farm neighbours who come together to break pods for a member against the promise of that member reciprocating. When asked if he uses this type of labour for breaking his pods, a 49-year-old male farmer in Juaboso responded, "We do that by groups so you should be a member of a group. Once you are a member they will come and assist".

However, other farmers argued that due to the insincerity of people these days they preferred to hire labour paid in cash and food.

The commodification of labour and especially family labour accounts for the weakening moral economy of self-help. For some they prefer not to have the obligation to the group. The availability of capital to pay for hired labour also explains the declining interest in group labour. The most frequent reason given was that group members reneged on their responsibilities and obligations, creating mistrust and a sense of being cheated.

\subsubsection{Hired labour}

Hired labour covered shortfalls in household labour especially on large farms. Farmers' children only helped when they were strong enough and on holidays from school, giving a small window of time. Spouses who worked other jobs and were unable to dedicate their time to family farms resorted to the use of hired labour.

'When I have to spray and harvest while my husband is not around, I hire labourers to do these jobs. I sometimes also need to weed and because the farms are big, I have to take labourers. I invest a lot in labour'.

(Elderly female cocoa farmer from Abrokofe, November 2019).

Most small farmers relied solely on family labour:

'No, I have never hired labourers to work on my farm. The reason is that my farm size is relatively smaller compared to others. Another reason why I don't prefer hiring labourers is that hired labourers usually do not work to satisfaction. Often times, we see farmers or farm owners

Table 4.3: Proportion of respondents who worked for others for more than 10 days in last 12 months

\begin{tabular}{|l|c|c|c|}
\hline & Male & Female & Total \\
\hline Farm labour & $26(15 \%)$ & $8(7.7 \%)$ & $33(12 \%)$ \\
\hline Casual employment, not on farms & $22(13 \%)$ & $16(15 \%)$ & $37(14 \%)$ \\
\hline Formal employment & $10(5.8 \%)$ & $2(1.9 \%)$ & $11(4.3 \%)$ \\
\hline Skilled worker: Mason, Carpenter, Mechanic, etc. & $33(19 \%)$ & $16(15 \%)$ & $48(18 \%)$ \\
\hline Running business, such as a shop & $38(22 \%)$ & $40(38.5 \%)$ & $76(28 \%)$ \\
\hline
\end{tabular}

Source: Authors' own

Table 4.4: Use of hired labour: the number of famers hiring for specific tasks

\begin{tabular}{|l|c|c|}
\hline Day contract labour hired: & Male & Female \\
\hline Weeding & $101(59 \%)$ & $68(65 \%)$ \\
\hline Harvesting & $84(49 \%)$ & $52(50 \%)$ \\
\hline Pruning & $66(38 \%)$ & $46(44 \%)$ \\
\hline Land clearance & $22(13 \%)$ & $20(19 \%)$ \\
\hline
\end{tabular}

Source: Authors' own 
engaged in fights with labourers they hired to work on their farms because the labourers did not work to the satisfaction of the farm owners'.

(40-year-old male cocoa farmer, Abrokofe, November 2019).

Hiring of labourers has over time become important for all categories of farmers. Labourers are generally available once the farmer can pay. At peak times, even hired labour may run short. Social relations built over time then determines who gets labour first. Kind farmers who provide other incentives beside the wage usually have a dedicated labour crew to choose from.

Labourers may be indigenes, Togolese or northerners. Most indigene small farmers hired out their labour for funds to invest in their own farms and meet other bills since their farms did not generate enough to meeting living costs. Table 4.3 presents the results of the household survey on the proportion of respondents who worked for others for more than 10 days in the last 12 months. Providing labour on other people's farms was an alternative livelihood for a few farmers, mainly male (Table 4.3). About 15 per cent of male and 7.7 per cent of female farmers reported working on other people's farms for more than 10 days in 12 months prior to the study. Most indigenes hiring out their labour were youth without cocoa farms, especially those left out of family inheritance (see section 3.2.1).

The household survey also showed that farmers hired labourers for arduous and time-consuming tasks, especially weeding, harvesting and pruning (Table 4.4). Almost all plots were worked in part by hired labour for one or other task, but the median amount of hired labour was low: 4.5 days per acre or 11 days per hectare.

\section{Availability of labour}

Although labour can still be hired in all threecommunities, as long as the farmer can pay, the number of labourers is declining. For example, one interviewee stated that 'labourers were quite readily available 10 years ago compared to now. These days the labourers are not as much as they were 10 years ago' (27-year-old male cocoa farmer, Abrokofe, November 2019).

The emergence of (illegal) small-scale mining (galamsey) in cocoa communities was one reason for less labour:

'People would rather engage in galamsey than become a farm labourer because the galamsey business is known to pay more than the farm labour. In a day, a galamsey labourer could earn a minimum of GHC50 [US\$8.3] while a farm labourer earns a maximum of $\mathrm{GH} \mathbb{C} 30$ (5\$)'. (27-year-old male cocoa farmer, Abrokofe, November 2019).

'It is difficult to access labour because of the galamsey operations. Most of the people have stopped the cocoa caretaker job. The same applies to labourers. You see these young men returning home (pointing to men walking towards us) went for galamsey. They earn about GHC100 [US\$17] a day, so they will not go to work as a labourer in your farm just to earn GHC25 [US\$4.2] or GHC30 [US\$5]'.

(42-year-old male cocoa farmer from Abrokofe, November 2019).

Fewer migrants come to work in Sefwi today than before, although enough come from the north, Volta and Togo for peak season tasks such as weeding and harvesting. Migrants often come in groups, so they can carry out contracted work rapidly and also for company and solidarity. They lead hard lives, basing themselves in one or two other places, then coming to Sefwi for peak seasons. They have to cover costs for travel and accommodation themselves.

\section{Forms of hiring}

Forms of hiring included hiring by day or by piece rate. One 42-year-old day labourer described a typical workday when paid by day, stating that 'when you take by day work, you start from 7am and by 11 or 12 noon, you close. If you go and start work, once it is 12 noon you will close. The charge is GHC25 [US\$4.2]' (Day labourer, 42 years, Juaboso Nkwanta).

By-day labour can be deployed for all tasks and at short notice. Farm wages rise with the price of cocoa, reflecting a fair wage. The day rate increased from GHC20 [US\$3.3] to GHథ25[US\$4.2] per day in 2018. As one female cocoa farmer explained, 'anytime there is an increment in prices of cocoa labourers also increase their charges. Maybe it was twenty (GHC20 [US\$3.3]) but once there is an increment, they will also increase it to about GHC25 [US\$4.2]' (Female cocoa farmer, Abrokofe, November 2019). Harvesters are paid more for their skill and because it is considered hard work, while all other tasks ranging from carriers to pod breakers receive the same amount of $\mathrm{GH} \mathbb{2} 25$ [US\$4.2] a day.

Other factors can increase wages such as labour shortages, diversion to other crops and small-scale mining, while arriving migrants relieve shortages.

Bargaining for a lower price only happens for food crops, but not cocoa which is a commercial crop with a guaranteed price. Commercial crops with higher prices 
tend to guarantee better wages for labourers than food crops with unpredictable prices in local markets.

Farmers also provide food to labourers to incentivise them to perform at their best. Where the farmer has no time to cook, they provide a top-up for the labourer to buy food.

Labour may also be hired on piece rates, or Adopaa, where a specific amount is paid for a measured task, such as GH\$100 [US\$17] per acre [0.4ha] of weeding or pruning. Tasks such as weeding and spraying are typically contracted out on piece rates. This may be paid there and then or can be on credit, to be paid after the cocoa beans are sold. Those prepared to work on credit come from outside the community, and charge more as some interest is factored in. This suits farmers who lack cash:

'Yes, we have resident labourers in the community and then there are those who come from other places like Togo as well. We have some labourers who offer their services on credit. They agree with the farmer to do what is required of them on the farm and then during the harvesting season they come back for their payment'.

(30-year-old male cocoa farmer, Abrokofe, November 2019)

According to interviews with farmers, this category of labourers is made up mostly of migrants from Togo:

"I go for the long-term labourer (adopaa) because you can engage their services on credit. As for the by-day [labourers]... you have to pay them at the end of the day but the long term labourer will take the money after you harvest and they weed, cut mistletoe and do other things you require of them'.

(52-year-old male cocoa farmer, Abrokofe, November 2019).

"They [labourers from Togo] come in groups of about five. When you hire them like that the work moves faster so if you want it done quickly, you go for them. You are responsible for their food and accommodation because they are strangers. So, you can agree to give them a certain amount of money for food so they are able to do the work or that they can take some food crops from the farm to feed themselves'.

(52-year-old cocoa farmer, Gyasehene, Abrokofe, November 2019).
Deferring pay involves trust. Migrants may weed in March to May, then return to the community after harvesting in October to get their money.

'Usually when these labourers come, they work on multiple farms and write the names of the farmers and amount owed them down. So, when it is harvesting time, they come back to the communities and go to these famers to collect their monies. Usually, they measure the farm by acre and charge you. If they are weeding the cocoa farm, they charge about GHC100 [US\$17] per acre. When the farm is maybe a food crops farm, they may charge between GHC50 [US\$8.3] to GHC80 [US\$13.3]. Sometimes you can negotiate with them and they will take GHC50 [US\$8.3] for weeding the food farm. When the harvesting season is in, they then come for their money. Even yesterday we made a public announcement that those who came to do the credit labour are back to the community so those who owe them should pay them.'

(Male focus group, Antobia, 2019).

Unfortunately, this trust is not always honoured. Participants in focus groups bemoaned the behaviour of some farmers who did not pay labourers as promised. This can be a headache for migrants.

'Yes, and there is this woman and she wants to play smart but she is not smart. We came to do the work and when we checked the size of the farm, it was four acres [1.6ha] and a little more. She has not settled anything at all; the GH\$400 [US\$67] she is supposed to pay us - when we go to her, she says "tomorrow" ... The other day we went to see her, she shouted all of a sudden and said, "I have GH\$100 [US\$17], how much money is left?". My father took that money and I told him to give the money back to her because she is saying she doesn't know us. He should give her GHC100 [US\$17] back to her; I don't want to take it ... This morning, I went to see her, she said that we should follow her to the farm to go and check the size of it. For another person, his total debt is GHC880 [US\$147]. I went to see him in the morning, and he said he is going to harvest cocoa and come...Another person owing GHC450 [US\$75] also said he is going to harvest cocoa and come. For the rest, I haven't seen them yet. That is the issue'. 
(Interview with a 53-year-old migrant from Togo) ${ }^{6}$

Migrants have little power when a farmer reneges. If they complain to the police, they must pay them to come to intervene. Leaders and elders encourage farmers to pay up, but they can only try to persuade farmers to act honestly.

\subsubsection{Caretaker labour}

Instead of hiring by the day or task, farmers may contract caretakers to carry out most of the farming. Situations where they might do so include where the farmer is old, too ill to work, or simply has lands that are too large to manage alone. The results of the study showed that this practice is not common with caretakers only employed on 14 per cent of the plots surveyed.

Caretaker labourers stayed within the community either temporary or permanently, unlike migrant labourers who circulated.

Two caretaker systems operate in Juaboso. The first form of caretakers are annual labourers, young men mostly from the north who join the farmer's household to take care of the farm. If they live with the farmer, they may also perform household tasks. A contract is normally agreed, stating the amount to be paid at the end of the year irrespective of cocoa output, plus the responsibilities of the farmer to feed, house and meet medical care, etc. Agents who supply these labourers from the north are mostly family members such as uncles and brothers who usually receive a payment on behalf of the family. Some focus group informants believed that caretakers were being cheated both by the farmer and their agents or families. It was possible to have older, indigenous caretakers but focus groups reported that they were not common.

The second type of caretakers, well documented in the literature, receive a third of harvest for their services. These are called the abusa labourer but they are not the same as the abusa tenant. They have no entitlement to land but merely work for a share of the crop. Since their rewards are linked to crop yields, they have an incentive to take good care of the farm. They work under an arrangement agreed upon by both parties:

'We have the caretaker labourer, like what I am practising. What happens is that in caretaking, which we call "Abusa", the owner plants the land and gives it to someone to maintain (weeding, cutting of mistletoe, etc). The owner is also responsible for buying chemicals for spraying and fertilisers. Then when you harvest, you divide the produce into three parts, the owner takes two and the caretaker takes one'.

(42-year-old male cocoa farmer, Abrokofe, November 2019).

This arrangement is universal across all communities as stated by another female farmer:

'The arrangement is that I buy the chemicals, pay for labour and buy fuel for spraying while he maintains the farm by weeding, cutting mistletoe and general maintenance work. When it is time for harvest, we divide into three, I take two and he takes one'.

(Female farmer, Abrokofe, November 2019)

Some farmers even engage hired labour to help the caretaker when farms are large, or the task needs to be done swiftly. A 42-year-old male cocoa farmer spoke about the expectations of caretaker labourers:

'Weeding three times a year, cutting of mistletoe 2 times a year, if he knows how to spray and you have the machine then he will spray while the wife fetches the water. If he hires someone to do the spraying, then he will have to bear the cost. If the farm owner does not have the machine, then hiring the machine becomes the cost of the farm owner. But even if you have the machine and he doesn't know how to operate it then you the farm owner can do the spraying to prevent the destruction of the machine'.

(Male cocoa farmer, 42 years, Abrokofe, Nov. 2019).

Caretakers also have an association whose members help each other on a routine rotation. Thus, most of the work expected of them is done in groups. This lessens the need for caretakers to engage hired labourers to weed and perform other activities expected of them thus reducing costs. The story of Toledo in Box 3.2 shows the circumstances of caretaker abusa labourers.

Environmental conditions, diseases, input use, cost of extra labour and the price of cocoa determine caretakers' wages. The nature of the contract affects the welfare of caretakers positively or negatively. For instance, caretakers may be allowed to grow food crops both for subsistence and possible sale, they may get loans from farmers, and they may be treated as household members in meeting their basic needs and not be taken advantage of through expulsion before

$6 \quad$ For the migrant in question, the problem was unexpected and unwelcome. The subject took up much of the interview. The migrant was clearly at his wit's end. 
the cocoa harvest. On the other hand the caretaker may not have most of these privileges thereby making it a retrogressive contract.

Relations between caretakers and landowners are not coldly contractual, but social. Trust matters. Landowners run the risk that the caretaker takes the harvest, sells it, and disappears. For this reason, one caretaker told us that landlords were reluctant to allow unmarried young men to take care of their cocoa. Caretakers, on the other hand, run the risk that the landlord acts unfairly, perhaps telling them to leave before the harvest. On the other hand, both parties gain from close and cooperative relations. Caretakers turn to their landlords in emergencies, for example when they have medical bills.

\subsection{Gender and labour}

\subsubsection{Gender norms and practice}

Gender norms apply to working on cocoa farms with some tasks, requiring physical strength or being dangerous, seen as men's work. Cutting mistletoe, for example, involves climbing and the risk of falling, while cocoa harvesting puts labourers at risk of pods falling on their heads.

In one female focus group discussion, women spoke about women's roles on cocoa farms:
F8: The women plant the cocoa. Sometimes both the woman and the man clear or weed the farm. We also hire labourers to support. The woman plants the cocoa and the food crops.

F3: The woman only weeds around the trees but the man handles the rest.

F8: The woman cannot prune the tree. Some of the men do not even know how to do it so they go to the Department of Agriculture to get people to do it.

F2: Some women climb the trees to prune it but others are afraid that they might fall down from the tree.

(Female focus group discussion, Juaboso Nkwanta)

Norms were formed from the start of cocoa planting in Ghana. Women were assigned the tasks of carrying cocoa pods when hiring labourers during the harvest. Hill (1963) notes that women were often carriers, but never labourers for other tasks in the early days of cocoa in Ghana. However, over time, women's roles have diversified into other forms of labour such as weeding and processing cocoa.

While these are the norms, practice often differs. On household cocoa farms not yet split or gifted to women, men weed, harvest and dry while women

\section{Box 4.2 Toledo the migrant caretaker from Bawku, Northern Ghana}

Toledo (not his real name) is a 22-year-old migrant caretaker from Bawku in the Upper East Region with one wife and no children. He takes care of three farms totalling six acres [2.4ha]. He has been a cocoa farm caretaker for the past nine years since his teenage days. The last two towns he worked in were not remunerating as he considers years of serious struggle without any progress. He is happy with his location where he considers his relationship with farm owners as good and the yields as much better than his last two destinations.

His contract with the farm owner requires that the farm should not be weedy, pruning of parasitic plants like mistletoe (Nkranpan), harvesting cocoa pods and drying them, and preventing people from stealing cocoa. The farmer provides fertiliser and other chemicals, while he absorbs the cost of transporting cocoa beans home and labour for breaking cocoa pods. These are normally deducted before the sharing of proceeds from sales. As an abusa labourer, when cocoa is sold, the money is divided into three, the owner of the farm taking two shares while Toledo gets one. He has no written contract but a verbal one with two witnesses that follows laid down rules of abusa contracts in the Sefwi Wiawso Kingdom.

He is part of a labour group for harvesting cocoa, but all costs including feeding and entertaining the group is borne by him, however he can borrow money from the farmer to be deducted when beans are sold. A part of his payment for the third harvest in the year is kept by the farmer as a guarantee in case he abandons the farm. He is constantly working as the weeds grow quickly, leaving him with no rest at all.

He has fallen a couple of times, dislocating his shoulders and breaking one arm. The payment for his hard and risky work depends on the amount of cocoa harvested. He therefore has a vested interest in making sure all is done right to produce a good harvest. 
carry pods and beans. For male farmers with multiple farms and multiple wives, each wife is usually given a dedicated farm to work on. She carries out all activities, particularly weeding, while the husband rotates around the farms to cut mistletoe, apply chemicals, harvest pods and eventually sell the cocoa to buying agencies.

Establishing a cocoa farm, especially from secondary forest, is considered the most demanding phase in cocoa production. Most farmers who acquired lands while married admitted that they cleared the land with help from their spouses which presupposes women could and did carry out tasks described as male.

In the absence of men, women farmers may carry out male tasks. Women farmers rely mainly on their own labour and that of their children, with occasional use of hired labour. A few women admitted knowing how to harvest cocoa pods during the female focus groups, but most relied on male harvesters, or their husbands and grown children for harvesting. Over the years women have learned to engage in all aspects of work on cocoa farms, though their labour in some domains is not acknowledged. For example, in a female focus group discussion, one woman spoke about her knowledge of harvesting pods, stating,

'it is mostly males who do that work. I know how to harvest cocoa but they will not hire a woman to do it. They mostly prefer the men'.

The demand for female labour is very high during the harvest season. Similarly, men have also become cocoa pod carriers due to weeding tasks being unavailable during the harvest while the demand for carriers goes up. By-day labourers of both sexes take up these jobs thereby breaking age-old gender barriers.

It seems that some of the gender division in labour has broken down when people work on their own or family farms, with perhaps the exception of harvesting which is generally seen as a job for men.

\subsubsection{Gender and the labour market}

When it comes to the labour market, gender norms are reasserted. Women are offered 'women's jobs', men are offered the 'men's jobs' - and men are often paid better for these roles because they are seen to be arduous, skilled or dangerous.

Both men and women reported being paid the same for jobs such as carrying cocoa and breaking pods.
However, some tasks dominated by men, such as harvesting cocoa, are paid higher. Those who harvest earn the highest wages because this is specialised work, involving more effort with the risk of being hit on the head by falling pods. The refusal to hire women on grounds of tradition and the excuse of protecting them from hazards deprives daring women of a good source of income.

Although many women join the wage labour pool for tasks such as weeding, there is still a preference for males. Weeding is considered tedious, so fewer women are hired to provide this service. However, women typically weed on their family farms while the men provide the service on the labour market for cash. One 94-year-old male farmer who replanted eleven acres of his 22-acre [8.9ha] farm preferred hiring women, stating, 'I have employed nine different women to work on my farms. I have shared the farms into portions for them and so each person works on their own portion'.

This farmer was once married to eight women who were caretakers of his farms but now has one wife after divorcing the rest, hence his appreciation of the work of women compared to men. There is growing respect for women's ability to do cocoa jobs, even if most of the hiring is to carry pods.

Women hire labour less than men. Many women cannot hire labour for lack of cash due to having small farms and fewer opportunities to earn wages than men. Some women therefore rely on credit labour during mostly high labour demand seasons:

'We do hire labour but because we don't have enough money, we hire them on credit. They come to the farm to work maybe in the fifth month and they will come back in the eleventh month for their money. So, as I sit here, I am in debt and I need money to pay for that. The men are not there to support us anymore. Farming is tedious and we need support'.

(F8 speaking at a female focus group discussion in Juaboso Nkwanta, November 2019

Given the incentive to work for pay on the day, wellcapitalised men usually obtain labour before women, with multiple benefits of meeting deadlines for specific farm activities which are critical to obtaining higher yields. 
Ever since cocoa has been grown in Ghana since the late nineteenth century, cocoa farming has depended very largely on getting land and finding the labour to cultivate it. Capital has been scarce but a lesser concern: cocoa has until recently usually not required heavy cash outlays on inputs. For the first one hundred years or so of cocoa in Ghana, the industry has developed by planting new lands - both to expand the total area and to replace older groves abandoned to swollen shoot. The main findings were as follows:

Gaining access to land was not difficult. For household offspring, there was the land worked by their parents and lineage elders that could be inherited. If division among offspring meant too little land, then land could usually be had by moving to the forest frontier. Chiefs would allocate land to incomers for nominal fees, so long as the farmers were prepared to plant up the land allocated.

Finding labour was the greater challenge. Family labour could be put to work, so long as there was the promise of inherited land to reward working for family elders. This could be supplemented by migrant labour, recruited from parts of Ghana and territories to the north, where population pressure was high upon semi-arid lands of low potential. For migrants, earnings from working in cocoa became a vital support to the livelihoods of the north of the country.

In the last 60 years, circumstances have changed in Sefwi. The land frontier has closed as forests have been declared reserves and as the rest of the forest has been already cleared for cocoa and other crops. It is no longer possible to ask a chief for a plot in the forest to farm: free forest is gone.

Family labour has also become scarcer as children go to school and their work in the cocoa groves is restricted by labour laws. Other activities compete for household labour including crops such as rubber and oil palm, galamsey mining, jobs in local market centres, and migration to the cities.

Cocoa farming has become more difficult as groves of old trees - aged 30 years or older - enter in decline and need replanting, and as pests and diseases increase - with the most damaging being swollen shoot, for which the only remedy is to cut, burn, then replant with clean stock.

In response to these three challenges, the institutions governing access to land and labour have changed, but gradually, with adaptation and evolution of longstanding institutions rather than transformation and revolution. So, what has changed?

\subsection{Land: the new norms}

The biggest change has been that land, once vested in the lineage and held on behalf of the very extended family, with inheritance down the matrilineal line through the mother's brother (wofa), has given way to land controlled by the nuclear family, passed down the paternal line. This is a sharp break with longstanding Akan custom. It has, however, taken place with little social rupture.

Matrilineal inheritance was progressively challenged by men with land they had cut from the forest, or bought, who claimed that this was their land, not land that had been passed down within the lineage, and hence they could dispose of it as they wished. To make sure that when they died lineage elders could not reimpose their will, they often passed on their lands in their final years as gifts to their offspring, paying due respect to custom by having ceremonies with witnesses and reporting transfers to chiefs - with small gifts to chiefs and elders to ease their recognition of the rights transferred. This has led to much land was being passed down the generations along paternal lines from one generation's nuclear family to the next generation's nuclear family. There seems to have been little resistance to this from elders or chiefs. In our interviews, elderly respondents recorded these changes, but seem to acquiesce to them.

At the same time, it seems the rights of girls to inherit land have increasingly been recognised. Women farmers interviewed had less land than their male partners, but they had land - either inherited from their father, or which had been shared with them by their husband.

Land tenure was not necessarily efficient, in that more than one third of plots were yielding very little cocoa - in part because the farmers lacked labour or capital 
for inputs to make their plots more productive. That problem, however, was closely linked to the rising costs and challenges of cocoa production: old trees needing replanting, and attacks of swollen shoot, insect pests, fungi and mistletoe.

Land tenure was not equitable, either. That did not, however, mean either that land was being monopolised so that a class of landowners was able to extract rack rents from tenants; or that some farmers were accumulating land. If anything, through time, control over farmland tended to dissipate.

\subsection{Labour:" new opportunities, old institutions}

The institutions governing the availability of labour had not changed, but the degree of use of them had. Farmers were using less labour from their family. Exchange labour groups had declined, being limited to small groups that worked collectively on the hard work of breaking cocoa pods. Use of sharecropping caretakers or caretakers paid an annual fee was uncommon. Farmers increasingly were recruiting extra labour as hired hands, from gangs being paid piece rates.

When interviewed, some farmers reported that it was harder to recruit labour than before, owing to competition from mining and from jobs in rural market centres. However, they usually agreed that if you had the cash to pay, you could find labour.

Hence obtaining labour was also a question about capital.

While some observers thus see labour as being commodified, some arrangements only function with much trust and social affiliation - the farmer who puts up the annual labourer, a youth from the north, in his own house; or the Togolese gangs prepared to work and wait until the harvest, trusting the farmers to then pay them for their work. These are not the relations of hard capitalism, a gig economy in the forest, but more typical of relations seen across the world in farm labour - where much more than pay for work is transacted.

Landowners have good reason not to drive hard bargains: the workers hold the cards when it comes to how diligently they work. In cocoa groves, the owner cannot stand and watch labour in action: the trees get in the way. In any case, farms may be scattered plots, making supervision potentially time-consuming. Owners must trust their labour: it pays them to deal decently with hired hands.

Considerations of hiring labour should not be overplayed. Farmers were not using much hired labour: the median days reported in the survey was just 4.5 days/acre [ 11 days/ha], with a mean of 6 days/ acre [15.8 days/ha]. The bulk of the labour needed to farm came from the farmer and their immediate family. Labour hiring was concentrated on the two heavy demands: weeding early in the season and harvesting at the end of the season. Indeed, as cocoa farms become smaller with increasing population, hired labour may be becoming less important.

\subsection{Women at a disadvantage, even if some improvement has been seen}

Women are usually disadvantaged in both land and labour. Women are likely to get smaller shares of inherited land than men. When husbands die, men can take advantage of widows, cloaking their land grabs under cover of lineage rules. When hiring out their labour, women are restricted to the lowest paid tasks and their skills are generally not recognised.

Some of the interviews suggest that these inequalities are lessening. Patriarchs are more likely to pass on some of their land to their daughters. Some farmers see that women can carry out tasks seen as skilled and male. Nevertheless, the inequalities remain. It is easier for men to grow cocoa than women.

\subsection{Reflection}

We end the discussion on a note for reflection. While Ghana still had a forest frontier on which to plant new cocoa groves, mobilising land and labour that began in the 1880s remained critical to the sector. Today that has ended. No frontier remains: the groves run up to the Ivorian border. That removes one source of profit: the forest rents from newly cleared land. The demand for chocolate is growing, rising especially in Asian emerging economies.

Hence the challenge for the farmers of Juaboso Municipal, both Sefwi and strangers, is this: forest rents must be replaced by technical rents. The future lies with technical improvement, and with that, injections of capital. It is no longer primarily about mobilising land and labour. The new agenda invites questions about innovation, about state services, and about farmer access to capital to invest in upgraded cocoa. A subsequent paper will address these issues.

\subsection{Policy implications}

For policymakers, the following points deserve consideration:

Land tenure. It would be easy to recommend changes, such as legal codification of inheritance rules, formal registration of all land transactions, however 
these would be difficult to implement and any rules would be hard to enforce. Moreover, if new laws and regulations ran against local understandings of what is reasonable and fair, they would either be ignored or else might produce unwelcome side-effects - such as providing cover for the dishonest and unscrupulous to grab land. Central government might be wise to leave improvements to land tenure to local governments and the traditional authorities of chiefs and elders.

Capital. Considerable areas of cocoa are not farmed well because the farmers lack working and investment capital. Currently, very few if any farmers have access to formal credit, other than the small loans offered by purchasing clerks - which evidently are not enough to meet demand. Advancing funds to allow farmers to buy inputs and hire labour should be a reasonably safe investment: the additional cocoa yield should more than cover the repayments. The problem for commercial lenders is that farmers have many points of sale, allowing them to escape repayment by claiming they harvested less than expected. Several potential solutions may be imagined. One would be to encourage rural banks to offer cocoa farmers seasonal loans for inputs and labour, with repayments deducted from their cocoa sales. That would require all sales from cocoa farmers taking loans to be registered with purchasing companies who would make the deductions and send to the banks to cancel debts. With digital technology that should not be difficult.

To cover losses where farmers have suffered genuine misfortune and lost their harvests, insurance might be bundled with credits. That, however, would require some thought as to how claims could be verified without inducing dishonesty. The clearest way to do that would be to link claims to some proxy measure for failed harvests, but that is hardly possible when losses are likely to be idiosyncratic (limited to the farmer claiming), the result of unusually virulent attacks of pests, fungi and viral disease. 
Amanor, K.S. (2005) 'Global and local land markets: The role of the customary' in: J. Quan, S.F. Tan and C. Toulmin (eds.), Land in Africa: Market asset or secure Livelihood: Proceedings and summary of conclusions from the Land in Africa Conference held in London November 8-9, 2004. London: International Institute for Environment and Development (IIED).

Amanor, K.S., Yaro, J.A. and Teye, J.K. (2020) Long-Term Change and Agricultural Commercialisation in Ghanaian Cocoa,APRA Working Paper 31, Brighton: Future Agricultures Consortium. Available at: https://opendocs.ids. ac.uk/opendocs/handle/20.500.12413/15270 (Accessed: 4 OCtober 2021).

Arhin, K. (1988) 'Economic differentiation among Ghanaian migrant cocoa farmers', Institute of African Studies Research Review 4: 10-18.

Austin, G. (2014). 'Vent for surplus or productivity breakthrough? The Ghanaian cocoa take-off, c. 1890-1936',The Economic History Review, 67(4): 1035. https://doi.org/10.1111/1468-0289.12043

Beckett, W. (1944) Akokoaso: A survey of a Gold Coast village. London: Routledge.

Boni, S. (2005) Clearing the Ghanaian forest: Theories and practices of acquisition, transfer and utilisation of farming titles in the Sefwi-Akan area. Legon: Institute of African Studies, University of Ghana.

Bray, F.R. (1959) Cocoa development in Ahafo, West Ashanti. Legon: Faculty of Agriculture, University of Ghana.

Bukh, J. (1979) The village woman in Ghana. Uppsala: Nordic Africa Institute.

Crook, R.C. (2001) 'Cocoa booms, the legalisation of land relations and politics in Cote d'Ivoire and Ghana: Explaining Farmers' Responses', IDS Bulleti, 32: 35-45. Available at: https://doi.org/10.1111/j.1759-5436.2001. mp32001005.x (Accessed: 4 October 2021).

Dormon, E., Leeuwis, C., Fiadjoe, F., Sakyi-Dawson, O. and Van Huis, A. (2007) 'Creating space for innovation: the case of cocoa production in the Suhum-Kraboa-Coalter District of Ghana', International Journal of Agricultural Sustainability 5: 232-246. Available at: https://doi.org/10.1080/14735903.2007.9684824 (Accessed: 4 October 2021).

Duncan, B.A. (2010) 'Cocoa, marriage, labour and land in Ghana: Some matrilineal and patrilineal perspectives', Africa, 80(2): 301-321. doi:10.3366/afr.2010.0206.

Green, E. (2017). 'From Extensive to Involutionary Growth: A Dialectic Interpretation of the Boom and Busts of Cocoa Production in the Gold Coast', Journal of Agrarian Change, 17(3): 518-534.

Grier, B. (1992) 'Pawns, porters, and petty traders: women in the transition to cash crop agriculture in colonial Ghana', Signs: Journal of Women in Culture and Society 17: 304-328.

Hill, P. (1959) 'The history of the migration of Ghana cocoa farmers', Transactions of the Historical Society of Ghana 4: 14-28.

Hill, P. (1963) The Migrant Cocoa-farmers of Southern Ghana: A Study in Rural Capitalism. London: Cambridge University Press.

Hill, P. and Mcglade, C. (1957) An Economic Survey of Cocoa Farmers in Sefwi-Wiawso. Cocoa Research Series. Legon: Economic Research Division, University College of Ghana. 
Knudsen, M.H. (2007) 'Making a living in the cocoa frontier, Western Ghana: Diversifying incomes in a cocoa economy', Geografisk Tidsskrift-Danish Journal of Geography 107: 29-44. Available at: https://doi.org/10.1080/0 0167223.2007.10649567 (Accessed: 4 October 2021).

Kolavalli, S. and Vigneri, M. (2011) 'Cocoa in Ghana: Shaping the Success of an Economy', in: P. Chuhan-Pole and M. Angwafo (eds.), Yes Africa can. Success stories from a dynamic continent. Washington DC: World Bank.

Okali, C. (1974) 'Labour inputs on cocoa farms', in: R.A. Kotey, C.D. Okali and B.E. Rourke (eds.), Economics of cocoa production and marketing. Legon: Institute of Statistical, Social, and Economics Research (ISSER), University of Ghana.

Quaye, W., Ampadu, R. and Onumah, J. (2014) Review of existing land tenure arrangements in cocoa growing areas and their implications for the cocoa sector in Ghana - A Technical Report. Ghana: United Nations Development Programme (UNDP).

Sutton, I. (1983) 'Labour in commercial agriculture in Ghana in the late nineteenth and early twentieth centuries', Journal of African History 24: 461-483.

Takane, T. (2002) The cocoa farmers of southern Ghana: incentives, institutions, and change in rural West Africa. Chiba: Institute of Developing Economies, Japan External Trade Organization.

Urquhart, D. (1961) Cocoa. London: Longmans Green. 
Yaro, J.A., Teye, J.K. and Wiggins, S. (2021) Land and Labour Relations on Cocoa Farms in Sefwi, Ghana: Continuity and Change, APRA Working Paper 73, Brighton: Future Agricultures Consortium

\section{(cc) BY-NC-ND}

This is an Open Access report distributed under the terms of the Attribution-Non Commercial-No Derivs 4.0 Unported (CC BY-NC-ND 4.0) Attribution - You must give appropriate credit, provide a link to the license, and indicate if changes were made. You may do so in any reasonable manner, but not in any way that suggests the licensor endorses you or your use. NonCommercial — You may not use the material for commercial purposes. NoDerivatives - If you remix, transform, or build upon the material, you may not distribute the modified material. You are free to: Share - copy and redistribute the material in any medium or format.

https://creativecommons.org/licenses/by-nc-nd/4.0/legalcode

If you use the work, we ask that you reference the APRA website (www.future-agricultures.org/apra/) and send a copy of the work or a link to its use online to the following address for our archive: APRA, Future Agricultures Consortium, University of Sussex, Brighton BN1 9RE, UK (apra@ids.ac.uk)

All APRA Working Papers go through a review process before publication.

\section{Cc. Creative}

\section{DO YOU HAVE COMMENTS ON THIS PAPER?}

We would welcome your feedback on this working paper!

To provide brief comments, please follow this link to our short APRA Working Paper Feedback form: https://goo.gl/forms/1iVnXhhrIGesfR9

Agricultural Policy Research in Africa (APRA) is a programme of the Future Agricultures Consortium (FAC) which is

generating new evidence and policy-relevant insights on more inclusive pathways to agricultural commercialisation in sub-Saharan Africa. APRA is funded with UK aid from the UK Foreign, Commonwealth \&

\section{Development Office (FCDO) and will run from 2016-2022.}

The APRA Directorate is based at the Institute of Development Studies (IDS), UK (www.ids.ac.uk), with regional hubs at the Centre for African Bio-Entrepreneurship (CABE), Kenya, the Institute for Poverty, Land and Agrarian Studies (PLAAS), South Africa, and the University of Ghana, Legon. It builds on more than a decade of research and policy engagement work by the Future Agricultures Consortium (www.future-agricultures.org) and involves more than 100 researchers and communications professionals in Africa, UK, Sweden and USA. 